\title{
A comparison of biogenic iron quotas during a diatom spring bloom using multiple approaches
}

\author{
A. L. King ${ }^{1, *}$, S. A. Sañudo-Wilhelmy ${ }^{1}$, P. W. Boyd ${ }^{2,3}$, B. S. Twining ${ }^{4}$, S. W. Wilhelm ${ }^{5}$, C. Breene ${ }^{1}$, M. J. Ellwood ${ }^{6}$, and \\ D. A. Hutchins ${ }^{1}$ \\ ${ }^{1}$ Marine Environmental Biology, Department of Biological Sciences, University of Southern California, 3616 Trousdale \\ Pkwy., Los Angeles, California, 90089, USA \\ ${ }^{2}$ NIWA Centre for Chemical and Physical Oceanography, Department of Chemistry, University of Otago, P.O. Box 56, \\ Dunedin, New Zealand \\ ${ }^{3}$ National Institute of Water and Atmosphere, 301 Evans Bay Parade, Greta Point, Wellington, New Zealand \\ ${ }^{4}$ Bigelow Laboratory for Ocean Sciences, 180 McKown Point Road., P.O. Box 475, West Boothbay Harbor, Maine, \\ 04575-0475, USA \\ ${ }^{5}$ Dept. of Microbiology, The University of Tennessee, Knoxville, Tennessee, 37996, USA \\ ${ }^{6}$ Research School of Earth Sciences, Australian National University, ACT 0200, Australia \\ * now at: Northeast Fisheries Science Center/NOAA, 212 Rogers Ave., Milford, Connecticut, 06460, USA
}

Correspondence to: A. L. King (andrew.king@gmail.com)

Received: 20 August 2011 - Published in Biogeosciences Discuss.: 19 September 2011

Revised: 19 December 2011 - Accepted: 26 December 2011 - Published: 3 February 2012

\begin{abstract}
Biogenic $\mathrm{Fe}$ quotas were determined using three distinct techniques on samples collected concurrently in the subtropical Pacific Ocean east of New Zealand. Fe quotas were measured using radioisotope uptake experiments ( $24 \mathrm{~h}$ incubation), bulk filtration and analysis by inductively-coupled plasma mass spectrometer (ICPMS), and single-cell synchrotron x-ray fluorescence (SXRF) analysis over a sixteen-day period (year days 263 to 278 of 2008) during a quasi-Lagrangian drifter experiment that tracked the evolution of the annual spring diatom bloom within a counter-clockwise open-ocean eddy. Overall, radioisotope uptake-determined Fe quotas (washed with oxalate reagent to remove extracellular $\mathrm{Fe}$ ) were the lowest (0.5-1.0 mmol Fe:mol P; 4-8 $\mu \mathrm{mol} \mathrm{Fe:mol} \mathrm{C),} \mathrm{fol-}$ lowed by single-cell Fe quotas (2.3-7.5 mmol Fe:mol P; 17$57 \mu \mathrm{molFe}: \mathrm{molC}$ ), and the highest and most variable quotas were from the bulk filtration ICPMS approach that used the oxalate reagent wash, corrected for lithogenic Fe using $\mathrm{Al}(0.8-21 \mathrm{mmol}$ Fe:mol P; 4-136 $\mu \mathrm{mol}$ Fe:mol C). During the evolution of the spring bloom within the eddy (year days 263 to 272), the surface mixed layer inventories of par-
\end{abstract}

ticulate biogenic elements $(\mathrm{C}, \mathrm{N}, \mathrm{P}, \mathrm{Si})$ and chlorophyll increased while $\mathrm{Fe}$ quotas estimated from all three approaches exhibited a general decline. After the onset of the bloom decline, the drogued buoys exited the eddy center (days 273 to 277). Fe quotas returned to pre-bloom values during this part of the study. Our standardized and coordinated sampling protocols reveal the general observed trend in Fe quotas: ICPMS $>$ SXRF $>$ radioisotope uptake. We discuss the inherent differences between the techniques and argue that each technique has its individual merits and uniquely contributes to the characterization of the oceanic particulate $\mathrm{Fe}$ pool.

\section{Introduction}

Iron $(\mathrm{Fe})$ has a profound effect on phytoplankton growth in open ocean and coastal high nutrient, low chlorophyll (HNLC) regimes where the supply of Fe is low (Martin and Fitzwater, 1988; Coale et al., 1996; Hutchins and Bruland, 1998), and Fe thus helps set global biological production and 
export of organic matter via the biological pump (Sigman and Boyle, 2000). While there has been a considerable effort to characterize the spatial and temporal variability of dissolved $\mathrm{Fe}(\mathrm{DFe})$ concentrations and $\mathrm{Fe}$ limitation of phytoplankton in the world's oceans, only recently have researchers begun to address in situ Fe budgets - relating environmental $\mathrm{Fe}$ pools to Fe requirements of biogeochemically-significant organisms (Boyd et al., 2005; Sarthou et al., 2008; Bowie et al., 2009; Tovar-Sanchez and Sañudo-Wilhelmy, 2011).

A pool of $\mathrm{Fe}$ that is critical for understanding the marine $\mathrm{Fe}$ cycle but particularly poorly constrained is that within biogenic particles. The biological iron:carbon ratio $(\mathrm{Fe}: \mathrm{C})$ is a key parameter because it quantitatively couples $\mathrm{Fe}$ and C biogeochemistry (Fung et al., 2000), determining the effect of varying Fe supply on the biological drawdown of carbon dioxide in the surface ocean. In biogeochemical models, Fe:C ratios or Fe quotas are important for constraining phytoplankton Fe requirements, predicting oceanic nutrient limitation scenarios (Moore et al., 2002; Parekh et al., 2005), and quantifying the enhanced downward C export due to $\mathrm{Fe}$ addition (de Baar et al., 2005; Boyd et al., 2007). Fe:C ratios have traditionally been determined with $\mathrm{Fe}$ and $\mathrm{C}$ radioisotopes using phytoplankton cultures (Sunda and Huntsman, 1995) and natural phytoplankton communities (Schmidt and Hutchins, 1999), or by measuring cellular $\mathrm{Fe}$ and $\mathrm{C}$ with graphite furnace atomic absorption spectrometry (GFAAS) and gas chromatography, respectively (Martin and Knauer, 1973; Collier and Edmond, 1984). More recently, methods for determining biogenic Fe have included inductively-coupled plasma mass spectrometry (ICPMS) (Ho et al., 2003; Frew et al., 2006), and single-cell synchrotron $\mathrm{x}$-ray fluorescence (SXRF) (Twining et al., 2004b).

$\mathrm{Fe}: \mathrm{C}$ ratios of laboratory phytoplankton cultures vary between species and evolutionary lineages (Sunda and Huntsman, 1995; Quigg et al., 2003), and as a function of growth parameters such as dissolved inorganic $\mathrm{Fe}$ concentration, light availability, and growth-phase status (Sunda and Huntsman, 1997, 2004; Maldonado and Price, 2001). The predictable scaling of cellular $\mathrm{Fe}: \mathrm{C}$ to the external concentration of DFe in culture studies (Sunda and Huntsman, 1995; Tang and Morel, 2006) is less evident in the natural environment due to the omnipresence of poorly-characterized organic ligands, the ill-defined property of Fe bioavailability, and the effects of other environmental properties such as irradiance. A further confounding factor for field measurements is the natural heterogeneity of suspended particles that can include phytoplankton, zooplankton, bacteria, detritus, and abiotic/lithogenic particles. For these reasons, using the methods described above, Fe:C ratios of in situ suspended particle assemblages have been found to vary $>100$-fold from $\sim 3$ to $>100 \mu \mathrm{mol} \mathrm{Fe:mol} \mathrm{C} \mathrm{(Boyd} \mathrm{et} \mathrm{al.,} 2007$ and references therein). These measurements include natural samples, separated by various filter size-fractions of plankton or as single cells, from diverse oceanic regions under varying biogeochemical conditions and using different methodologies.
Across these various published studies, $\mathrm{Fe}: \mathrm{C}$ ratios appear to be highest among measurements made with GFAAS/ICPMS, followed by SXRF, and the lowest measurements from $\mathrm{Fe}$ and $\mathrm{C}$ radioisotope uptake (see data summary in Twining et al., 2004a). In contrast, Fe quotas of lab-grown diatoms determined using SXRF, GFAAS, ICPMS, and $\mathrm{Fe}$ and $\mathrm{C}$ radioisotope uptake gave similar results (Twining et al., 2003, 2004a).

Reported Fe:C ratios in natural samples also likely differ due to the inherent biases that each technique introduces to the Fe quota measurement. Bulk techniques using GFAAS/ICPMS are inclusive of the entire particle assemblage, and could be influenced by potentially large pools of $\mathrm{Fe}$ contained within lithogenic and detrital particles that are difficult to separate from biogenic particles. SXRF analyses are focused on a fraction of individual cells comprising a specific subset of the microbial community. Cells for SXRF analyses must be isolated and identified, and often exclude cells that are unidentifiable, rare, or too small for analysis. Both ICPMS and SXRF techniques thus provide differing measures of the reservoir of $\mathrm{Fe}$ and other elements such as $\mathrm{P}$ contained in cells. Neither of these methods directly measures cellular $\mathrm{C}$, which must be estimated by stoichiometric conversion from $\mathrm{P}$, by biovolume algorithms, or from parallel measurements using gas chromatography (Parsons et al., 1984). Fe and $\mathrm{C}$ radioisotope uptake, on the other hand, is a rate-based measurement derived from incubations that span hours to days. Uptake rates of $\mathrm{Fe}$ and $\mathrm{C}$ are directly measured by radioisotopes, but these might not be representative of cellular quotas, and could also be biased by bottle artifacts (Cullen, 1991).

Based on the large range and observed trends, it is apparent that a direct comparison between these methods is warranted using samples collected at the same time and location. The comparison determines whether the variability between previously reported $\mathrm{Fe}: \mathrm{C}$ ratios of natural plankton assemblages from disparate studies is due to spatial or temporal differences between sampling, or if the techniques themselves are significantly influencing the reported quotas. As part of a GEOTRACES process study, the FeCycle II project (Boyd et al., 2012; Nodder et al., 2012; Twining et al., 2012), we measured particulate $\mathrm{Fe}: \mathrm{C}$ ratios using ${ }^{55} \mathrm{Fe}$ and ${ }^{14} \mathrm{C}$ radioisotope tracers, and both $\mathrm{Fe}: \mathrm{P}$ and $\mathrm{Fe}: \mathrm{C}$ using single-cell SXRF analysis (with microscopy biovolume estimates for C) and ICPMS in combination with spectrophotometry and gas chromatography for $\mathrm{P}$ and $\mathrm{C}$, respectively. These coordinated measurements were made over the course of a quasiLagrangian experiment studying the annual spring bloom in subtropical waters east of New Zealand. Here, we present the resulting range in $\mathrm{Fe}$ quotas from both community and sizefractionated samples that were determined using the three techniques in the context of FeCycle II, and discuss possible explanations for the observed 100 -fold range in the quotas. 


\section{Methods}

\subsection{Cleaning protocols}

All equipment used during this study were rigorously acidwashed under trace metal clean conditions, including using dedicated clean areas and Class 100 HEPA-filtered laminar flow work spaces. All washing steps included rinsing 35 times with ultrapure $18 \mathrm{M} \Omega \mathrm{cm}^{-1}$ deionized water (Millipore MilliQ and Barnstead Nanopure). Polycarbonate bottles (PC, Nalgene) were cleaned using $1 \%$ Citranox (Alconox) soap solution for several days, then filled with $2 \mathrm{M}$ reagent or trace metal grade $\mathrm{HCl}$ (EMD) for several days, then finally filled with $0.01 \mathrm{M}$ ultrapure $\mathrm{HCl}$ (Omnitrace). Low density polyethylene (LDPE) and polypropylene (PP) bottles and vials were cleaned using $1 \%$ Citranox soap solution for several days, then placed in a $2 \mathrm{M}$ trace metal grade $\mathrm{HCl}$ (EMD; Fisher Chemicals) bath for several days, then filled with $2 \mathrm{M}$ trace metal grade $\mathrm{HNO}_{3}$ (EMD; Fisher Chemicals) and heated to $60^{\circ} \mathrm{C}$ for 2 days. Polycarbonate filters (Osmonics and Poretics) were acid-washed in $2 \mathrm{M} \mathrm{HCl}$ for 1 week (Cullen and Sherrell, 1999). Teflon vials (PTFE, $10 \mathrm{ml}$, screw-cap, VWR) used for digestions were initially cleaned in aquaregia ( $75 \%$ concentrated $\mathrm{HCl} / 25 \%$ concentrated $\mathrm{HNO}_{3}$ ) for 1 week, followed by refluxing with a $2 \mathrm{ml}$ solution of $71 \% \mathrm{HCl}, 24 \% \mathrm{HNO}_{3}$, and $5 \% \mathrm{HF}$ (all acids ultrapure, EMD Biosciences) in a $100^{\circ} \mathrm{C}$ water bath, then diluting and measuring the solution for trace metal concentrations using ICPMS (see below). This was carried out for several iterations until metal concentrations were both low and constant.

\subsection{Sampling}

Trace metal clean techniques were used throughout when collecting and manipulating samples. Seawater from 30 and $60 \mathrm{~m}$ was collected daily using a trace metal clean rosette equipped with 51 Niskin-X bottles on non-metallic Spectra line (Ellwood, 2008) between 04:45 and 06:15 LT on ten days of the sixteen day FeCycle II experiment $>200 \mathrm{~km}$ east of the North Island of New Zealand (19 September to 4 October 2008; Table 1). Sampling was conducted in the vicinity of a surface-tethered drifting buoy that was attached to a holey-sock drogue located at the midpoint of the surface mixed layer (Nodder et al., 2012). The Niskin-X bottles were tripped at desired depths using a preprogrammed General Oceanics pressure sensor system. After retrieving the rosette, Niskin-X bottles were removed and carried into a clean van and sub-sampled into PC and LDPE bottles. The sampling depths of 30 and $60 \mathrm{~m}$ used for this intercomparison study were largely within the seasonal mixed layer, with the exception of year days 269 and 270 when the $60 \mathrm{~m}$ sampling depth was below the mixed layer (Boyd et al., 2012).

\subsection{Fe and $\mathrm{C}$ radioisotope uptake experiments}

Seawater (collected at $30 \mathrm{~m}$ and $60 \mathrm{~m}$ ) was subsampled from the trace metal clean rosette for $\mathrm{Fe}$ and $\mathrm{C}$ radioisotope uptake experiments (Table 1). Triplicate PC bottles were filled with 11 seawater to which $0.2 \mathrm{nmol}^{55} \mathrm{Fe}$ and $2 \mu \mathrm{Ci}(74 \mathrm{kBq})$ ${ }^{14} \mathrm{C}$ were added. Bottles were double bagged in Ziploc bags and placed in a flow-through incubator cooled with ambient seawater and shaded $\sim 30 \%$ of surface light for $24 \mathrm{~h}$. Average mixed layer light intensity during the study ranged from $\sim 14-30 \%$ of photosynthetically available radiation (PAR) at the sea surface, with the exception of year days 269 and 270 when the $60 \mathrm{~m}$ samples were collected from below the mixed layer where light intensity was $<1 \%$ of surface PAR. Experiments were serially vacuum-filtered $(<10 \mathrm{~mm} \mathrm{Hg})$ onto a stack of $20 \mu \mathrm{m}, 5 \mu \mathrm{m}, 2 \mu \mathrm{m}$, and $0.2 \mu \mathrm{m}$ porosity polycarbonate filters ( $47 \mathrm{~mm}$ diameter) separated by frits in an allTeflon filter tower (Savillex). Each filter was then individually washed with oxalate reagent to remove extracellular $\mathrm{Fe}$ (Tovar-Sanchez et al., 2003). We excluded the solvent extraction step from Tovar-Sanchez et al. (2003) and instead used multiple copious $(5 \mathrm{ml})$ rinses with $0.2 \mu \mathrm{m}$-filtered trace metal clean seawater (Tang and Morel, 2006; Hassler and Schoemann, 2009) collected from within the study area using a trace metal clean fish pumping system. Radioactivity was measured onshore using liquid scintillation counting following the addition of Perkin Elmer OptiPhase High Safe cocktail.

$\mathrm{Fe}$ uptake was calculated using the liquid scintillation counts and daily ambient DFe concentrations (Ellwood et al., 2012), and normalized to size-fractionated chlorophyll concentrations. Size-fractionated chlorophyll concentrations (chlorophyll- $a$ retained on a $0.2,2,5$, and $20 \mu \mathrm{m}$ pore-size filters) were calculated as the arithmetic mean of measurements from duplicate samples using the non-acidification approach (Welschmeyer, 1994) and used for normalizing Fe and $\mathrm{C}$ uptake rates to a biomass metric. Phytoplankton POC would also be appropriate for normalizations of uptake rates, but size-fractionated POC was not collected. Although algal chlorophyll:C ratios can vary between samples for many reasons, ${ }^{55} \mathrm{Fe}$ and ${ }^{14} \mathrm{C}$ uptake were normalized to the corresponding size-fractionated chlorophyll values, and chlorophyll is factored out of the final calculated $\mathrm{Fe}: \mathrm{C}$ values used to compare radioisotope ratios to those from the other two techniques. Fe:C ( $\mu$ mol:mol) uptake ratios were calculated as in Schmidt and Hutchins (1999). Carbon uptake measurements were deliberately not corrected with $\mathrm{C}$ uptake in dark treatments. Because Fe uptake was evident during darkness in our $24 \mathrm{~h}$ incubations, for consistency we elected to present both $\mathrm{Fe}$ and $\mathrm{C}$ uptake as uncorrected rates. $\mathrm{C}$ uptake in the dark was likely only a small fraction of total $\mathrm{C}$ uptake (Boyd, unpublished data). 
Table 1. Dates during the study in which samples for Fe quotas were collected (Fe and $\mathrm{C}$ radioisotope uptake, radio; bulk filtration and ICPMS analysis, ICPMS; single cell SXRF analysis, SXRF), including day collected, latitude (lat) and longitude (long), and ancillary data including $\mathrm{nM}$ dissolved $\mathrm{Fe}(\mathrm{DFe})$ at 30 and $60 \mathrm{~m}$, and phytoplankton community structure at $30 \mathrm{~m}$ (cell types include Asterionellopsis glacialis, Asterio; other diatoms, other dia; total diatoms, total dia; dinoflagellates, dinos; autotrophic flagellates, flag; and monads).

\begin{tabular}{|c|c|c|c|c|c|c|c|c|c|c|c|c|c|}
\hline \multirow[b]{2}{*}{ year $d$} & \multirow[b]{2}{*}{ lat (S) } & \multirow[b]{2}{*}{ long (W) } & \multirow[b]{2}{*}{ radio } & \multirow[b]{2}{*}{ ICPMS } & \multirow[b]{2}{*}{ SXRF } & \multirow[b]{2}{*}{$30 \mathrm{~m} \mathrm{DFe}$} & \multirow[b]{2}{*}{$60 \mathrm{~m} \mathrm{DFe}$} & \multicolumn{6}{|c|}{ cells $\mathrm{ml}^{-1}$} \\
\hline & & & & & & & & Asterio & other dia & total dia & dinos & flag & monads \\
\hline 263 & 39.20 .83 & 178.36 .88 & & & $\mathrm{x}$ & $0.60^{*}$ & $0.10^{*}$ & 59.1 & 1.4 & 67 & 0.2 & 8.8 & 30.5 \\
\hline 266 & 39.23 .87 & 178.46 .89 & $\mathrm{x}$ & $\mathrm{x}$ & $\mathrm{x}$ & $0.59^{* *}$ & $0.10^{* * *}$ & 7.3 & 4 & 11.3 & 0 & 11 & 30.5 \\
\hline 267 & 39.23 .12 & 178.41 .44 & $\mathrm{x}$ & $\mathrm{x}$ & $\mathrm{x}$ & $0.12^{* *}$ & $0.12^{* *}$ & 89.2 & 14.8 & 104 & 0.4 & 4.2 & 43.6 \\
\hline 269 & 39.17 .73 & 178.44 .14 & $\mathrm{x}$ & $\mathrm{x}$ & & $0.16^{*}$ & $0.09^{*}$ & 12.8 & 11.7 & 24.5 & 0.2 & 16.1 & 111.2 \\
\hline 273 & 39.09 .70 & 178.40 .68 & $\mathrm{x}$ & $\mathrm{x}$ & $\mathrm{x}$ & $0.20^{* *}$ & $0.20^{* *}$ & 0.3 & 1.6 & 1.9 & 0.1 & 7.5 & 43.6 \\
\hline 275 & 39.07 .69 & 179.11 .60 & $\mathrm{x}$ & $\mathrm{x}$ & & $0.18^{* *}$ & $0.18^{* *}$ & 0 & 0.9 & 0.9 & 0.2 & 8.8 & 78.5 \\
\hline 278 & 39.25 .33 & 179.25 .46 & $\mathrm{x}$ & $\mathrm{x}$ & $\mathrm{x}$ & $0.10^{*}$ & $0.15^{*}$ & 0 & 4.4 & 4.4 & 0.1 & 21 & 34.9 \\
\hline
\end{tabular}

* DFe values from trace metal clean rosette, collected 30 min prior to samples collected for Fe quotas.

** DFe values from trace metal clean fish, collected $\sim 12 \mathrm{~h}$ after samples collected for Fe quotas.

*** $60 \mathrm{~m}$ DFe value from day 263 was used for ${ }^{55} \mathrm{Fe}$ uptake calculations.

\subsection{Inductively-coupled plasma mass spectrometry and particulate organic $\mathbf{P}$ and $\mathbf{C}$}

Seawater for suspended particulate samples (1-2.31) was also collected in triplicate for 30 and $60 \mathrm{~m}$ from the same trace metal clean rosette cast and on the same days as $\mathrm{Fe}$ and $\mathrm{C}$ radioisotope uptake experiments (Table 1). Particulate samples and $\mathrm{Fe}$ and $\mathrm{C}$ radioisotope uptake experiments were filtered using identical methodology (see above). In addition to the removal of extracellular $\mathrm{Fe}$, the oxalate reagent also removed extracellular P (Sañudo-Wilhelmy et al., 2004). Filters were placed in acid-washed $2 \mathrm{ml} P P$ microcentrifuge tubes (VWR) and stored at $-20^{\circ} \mathrm{C}$ until analysis. Procedural blanks (treated the same as samples) were collected for all pore size filters at multiple occasions during the sampling period ( $n=12$ for each pore size).

Particulate samples for ICPMS analysis were thawed and processed in a trace metal clean laboratory (Class 100 laminar flow fume hood) using a complete acid digestion protocol (Eggimann and Betzer, 1976). Sample and blank filters were placed in digestion bottles and refluxed in $750 \mu \mathrm{l}$ ultrapure $\mathrm{HCl}$ for $30 \mathrm{~min}$ in a $100^{\circ} \mathrm{C}$ water bath, then $250 \mu \mathrm{l}$ ultrapure $\mathrm{HNO}_{3}$ was added and refluxed for an additional $30 \mathrm{~min}$, then finally $50 \mu \mathrm{l}$ ultrapure HF was added and refluxed for $1 \mathrm{~h}$. Samples were cooled for at least $30 \mathrm{~min}$ between acid additions and extreme care was used to minimize contamination during refluxing and bottle opening/closing during acid addition. The final digest solution was diluted $(1: 5 v / v)$ using MQ water and transferred (with filter remnants) to acidwashed $15 \mathrm{ml}$ LDPE bottles (Nalgene).

${ }^{56} \mathrm{Fe},{ }^{27} \mathrm{Al}$, and ${ }^{31} \mathrm{P}$ were quantified with a magnetic sector field high-resolution inductively-coupled plasma mass spectrometer (Element 2, Thermo). The ICPMS was calibrated using a multi-element standard and calibration checked with the certified reference material SLRS-4 (National Research Council, Canada; recovery ranged 94-109\%). Prior to analysis, $150 \mu \mathrm{l}$ digested particulate samples, using care not to transfer filter remnants, were added to $850 \mu \mathrm{l} 5 \%$ ultrapure $\mathrm{HNO}_{3}$ spiked with a $1 \mathrm{ppb}$ In internal standard. Samples were introduced via an autosampler attached to a Teflon nebulizer (PFA-ST nebulizer, Elemental Scientific Inc.) coupled with a $\mathrm{PC}^{3}$ cyclonic spray chamber (Elemental Scientific Inc.). The ICPMS was tuned daily using a $1 \mathrm{ppb}$ In solution and mass offsets were corrected with a $5 \mathrm{ppb}$ multielement standard. Procedural filter blanks were also subjected to the same storage, digestion, dilution, and analysis processes, and these blank values were subtracted from sample measurements. $\mathrm{Fe}, \mathrm{Al}$, and $\mathrm{P}$ concentrations for filter blanks are shown in Supplement; Table 1. Particulate Al (PAl) values and a crustal Fe:Al molar ratio (0.18) from previously reported Australian dust samples (Frew et al., 2006) were used to calculate the lithogenic component of $\mathrm{Fe}(\mathrm{LFe})$ in the suspended particulate $\mathrm{Fe}$ pool ( $\mathrm{PFe}$ ) (Martin et al., 1989). The lithogenic contribution was then subtracted from the total PFe pool in order to calculate biogenic $\mathrm{Fe}(\mathrm{BFe})$.

Accompanying samples from the trace metal clean rosette for particulate organic carbon and nitrogen (POC, PON; $750 \mathrm{ml}$ ), particulate organic phosphorous (POP; $500 \mathrm{ml}$ ) were vacuum filtered onto $25 \mathrm{~mm}$ precombusted $\left(450^{\circ} \mathrm{C}\right.$ for $4 \mathrm{~h}$ ) GF/F glass fiber filters (Whatman). Samples for biogenic silica (BSi; $750 \mathrm{ml}$ ) were vacuum filtered onto $25 \mathrm{~mm}$ $0.6 \mu \mathrm{m}$ PC filters. POC and PON samples were dried at $60^{\circ} \mathrm{C}$ and returned to the lab for analysis using a 4010 CHNS Elemental Combustion System (Costech). Samples for POP and BSi were processed and analyzed colorimetrically (Solorzano and Sharp, 1980; Leblanc et al., 2005). 


\subsection{Synchrotron $x$-ray fluorescence}

Samples for SXRF analysis were collected from 30 and $60 \mathrm{~m}$ on the same trace metal clean rosette casts on seven of the ten days on which radioisotope uptake experiments were conducted and samples for ICPMS analysis were collected (Table 1). Samples were preserved with $0.25 \%$ EM-grade glutaraldehyde (final concentration) that had been passed through Dowex resin to reduce trace metal contaminants (Twining et al., 2003). Cells in unfiltered water were centrifuged at $1400 \times \mathrm{g}$ for 30 min onto 200 mesh gold TEM grids coated with a carbon/Formvar film (Electron Microscopy Sciences). Grids were immediately removed with Teflon-coated forceps, rinsed briefly with $>18 \mathrm{M} \Omega \mathrm{cm}^{-1}$ deionized water and allowed to dry in a darkened laminar flow hood. All sample preparation was performed with acidwashed plasticware in a Class 100 environment, and samples were stored dried until analysis. Within $24 \mathrm{~h}$ of collection, samples were examined using light (differential interference contrast) and epifluorescence ( $480 \mathrm{~nm}$ light to excite chl- $a$ fluorescence) microscopy to identify appropriate target cells on the grids and to categorize cells. Cells were placed into the following taxonomic groupings based on their size and appearance: autotrophic picoplankon, autotrophic flagellates, the centric diatom Asterionellopsis glacialis (which dominated the bloom), and "other diatoms". The cells were grouped according to the longest size dimension $(0.2-$ $2,2-5,5-20,>20 \mu \mathrm{m})$ to facilitate comparison with sizefractionated ICPMS data.

Cells were analyzed at the 2-ID-E hard x-ray microprobe at the Advanced Photon Source on three occasions between February 2009 and March 2010. Detailed descriptions of the instrument and technique are available elsewhere (Twining et al., 2003; Vogt et al., 2003). Incident x-rays were tuned to $10 \mathrm{keV}$ to enable the excitation of $\mathrm{K}_{\alpha}$ fluorescence for $\mathrm{P}$ and Fe. The focused spot size was adjusted based on the size of the target cells. For the picoplankton cells, a Fresnel zoneplate with a focal length of $10 \mathrm{~cm}$ and a focused spot of approximately $0.3 \mu \mathrm{m}$ was used. Step sizes during the 2$\mathrm{D}$ raster scans were chosen to slightly oversample the image and were approximately $0.2 \mu \mathrm{m}$. For the larger eukaryotic target cells, a Fresnel zoneplate with $20 \mathrm{~cm}$ focal length and a focused spot of $0.3-0.5 \mu \mathrm{m}$ was used. For these cells, step size was set between 0.4 and $0.5 \mu \mathrm{m}$. Detector dwell times were adjusted to ensure adequate $\mathrm{x}$-ray counting statistics and were typically $1-2 \mathrm{~s}$ for larger cells and up to $7 \mathrm{~s}$ for picoplankton cells. Full fluorescence spectra were collected at each pixel in the scans.

Element quantification was performed as described in Twining et al. (2004a, 2011). Briefly, spectra from the pixels representing the target cells were averaged and fit with a custom fitting software package (MAPS; Vogt, 2003). Spectra were also averaged for a background region near the cell representing the carbon/Formvar film substrate. Fit peak areas for the background were subtracted from cellular peak
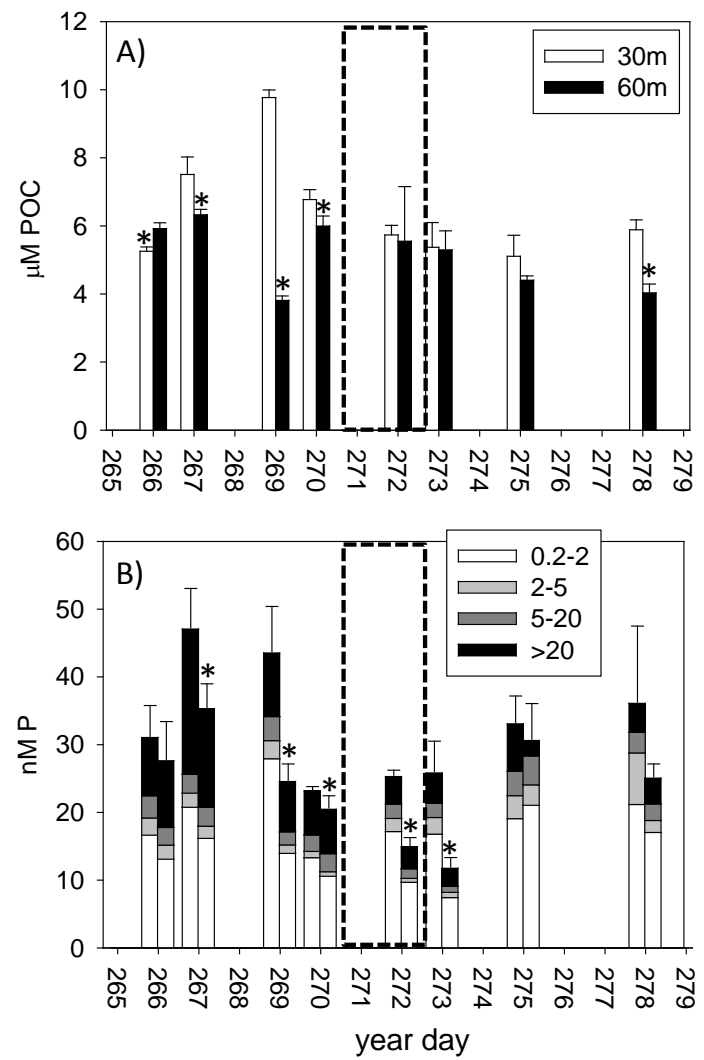

Fig. 1. Size-fractionated and total oxalate-washed particulate $P$ (P) from ICPMS analyses and particulate organic carbon (POC) by elemental analyzer at 30 and $60 \mathrm{~m}$ over the course of the experiment. (A) $\mu \mathrm{M}$ POC, $>0.7 \mu \mathrm{m}$; left bar (white) $=30 \mathrm{~m}$, right bar (black) $=60 \mathrm{~m}$. (B) nM P (oxalate-washed) by size fraction. Stacked data represent (top to bottom) the $>20 \mu \mathrm{m}, 5-20 \mu \mathrm{m}, 2-5 \mu \mathrm{m}$, and $0.2-2 \mu \mathrm{m}$ fractions; left $\mathrm{bar}=30 \mathrm{~m}$, right $\mathrm{bar}=60 \mathrm{~m}$. The transition between the two phases of the study (bloom inside the eddy and postbloom outside the eddy) is marked by the dashed line rectangle. Error bars represent 1 standard deviation $(n=3)$. Significant differences between $30 \mathrm{~m}$ and $60 \mathrm{~m}$ values are designated by an asterisk $(p<0.05)$.

areas. Areal concentrations were calculated for each sample from NIST thin-film standards (NBS 1832 and NBS 1833). Conversion factors for $\mathrm{P}$ were calculated by interpolation from the conversion factors for $\mathrm{Si}, \mathrm{K}, \mathrm{Ca}, \mathrm{Ti}, \mathrm{V}, \mathrm{Cr}, \mathrm{Mn}$, $\mathrm{Fe}, \mathrm{Co}, \mathrm{Cu}$, and $\mathrm{Zn}$ (Nunez-Milland et al., 2010). Cell volume was calculated from measurements of cell length and width using digital image processing software (ImagePro Plus). Shape and volume equations were taken from Hillebrand et al. (1999). Cellular C was calculated from cell volume using the "revised Strathmann" equations (MendenDeuer and Lessard, 2000) as during previous work (Twining et al., 2004a, 2011).

Cellular $\mathrm{Fe}$ quotas were calculated for each cell relative to $\mathrm{P}$ and $\mathrm{C}$. Ratios were log-transformed prior to statistical analysis to normalize the data and stabilize variance. Outliers 

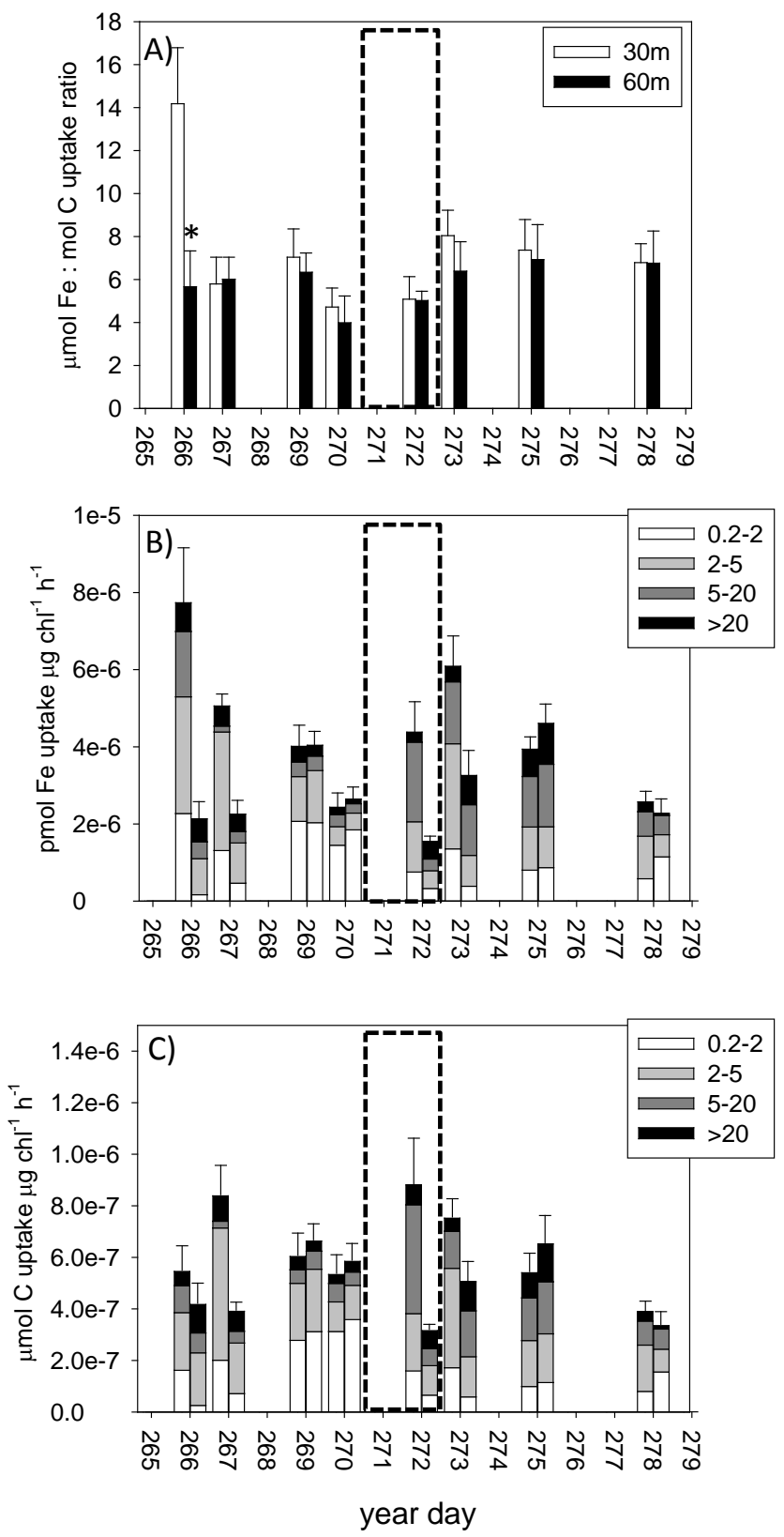

Fig. 2. Radioisotope-based Fe:C uptake ratios and chl-normalized molar Fe and $\mathrm{C}$ uptake rates from samples collected at 30 and $60 \mathrm{~m}$ over the course of the study based on $24 \mathrm{~h}{ }^{55} \mathrm{Fe}$ and ${ }^{14} \mathrm{C}$ incubations. (A) Total $\mu \mathrm{molFe}$ :molC uptake ratios calculated using Fe and $\mathrm{C}$ radiotracer uptake; (B) total chl-normalized Fe uptake ( $\mathrm{pmol} \mathrm{Fe} \mu \mathrm{g} \mathrm{chl}^{-1} \mathrm{~h}^{-1}$ ) and stacked by size fraction, and (C) Total chl-normalized $\mathrm{C}$ uptake ( $\mu \mathrm{mol} \mathrm{C} \mu \mathrm{g} \mathrm{chl}{ }^{-1} \mathrm{~h}^{-1}$ ) and stacked by size fraction. Stacked data represent (top to bottom) the $>20 \mu \mathrm{m}$, $5-20 \mu \mathrm{m}, 2-5 \mu \mathrm{m}$, and $0.2-2 \mu \mathrm{m}$ fractions. For each day, left bar $=30 \mathrm{~m}$, right $\mathrm{bar}=60 \mathrm{~m}$. The transition between the two phases of the study is marked by the dashed line rectangle. Error bars represent 1 standard deviation $(n=3)$ for total values. Significant differences between 30 and $60 \mathrm{~m}$ total values are designated by an asterisk $(p<0.05)$. were identified and removed using two criteria. First, cells were removed if the error estimated for the spectral fit produced using MAPS software was greater than $20 \%$ of the peak magnitude (peak $/ p_{\text {error }}<5$ ). Second, cells were identified as outliers on the basis of poor fit to an ANCOVA model that included sampling date (nominal classification), sampling depth (nominal classification), log cell biovolume, and cell type. Outlier analysis is necessary to identify cells compromised by spectral interferences (particularly from neighboring grid bars) or poor physiological condition (e.g. empty diatom frustules). Model analyses were made using JMP software (v. 6.0, SAS Institute). Jackknifed studentized residuals of this model were calculated, and all observations with values $>3.5$ were excluded from further analysis (Zar, 1996). Using this approach only one cell was removed from the dataset.

The element stoichiometries of the plankton groups were compared using geometric least-square (LS) means calculated by the ANCOVA model. These correct for differences in cell volume between the cell groups, as well as station and depth effects. Least-square means were also calculated for each station; these correct for variable numbers of each cell type at each station, providing a standardized point of comparison for examining temporal trends in $\mathrm{Fe}$ stoichiometries. Least-square means were also calculated for each cell size class $(0.2-2,2-5,5-20,>20 \mu \mathrm{m})$.

\subsection{Determination of dissolved iron concentration}

Seawater for DFe analysis was collected from 30 and $60 \mathrm{~m}$ with the same trace metal clean rosette equipped with 51 Niskin-X bottles on non-metallic line (as described above) and $\sim 7 \mathrm{~m}$ with a trace metal clean fish pumping system. Samples were not collected from the same casts used for collecting particulate samples, but were generally from the same day (see Table 1). Samples were filtered using acidwashed AcroPak $2000.2 \mu \mathrm{m}$ capsule filters (Pall). Filtrate were collected and acidified to $\mathrm{pH}<1.7$ with ultrapure $\mathrm{HNO}_{3}$. Dissolved Fe was preconcentrated using solvent extraction followed by determination by ICPMS. Briefly, $100 \mathrm{~g}$ of seawater was buffered to a $\mathrm{pH}$ of 4.5 with purified ammonium acetate buffer. Purified ammonium pyrrolidinedithiocarbamate (APDC) and sodium diethyldithiocarbamate (DDC) were added to the sample which was then extracted twice by shaking following the addition of purified chloroform. The two chloroform extracts obtained were combined, acidified with $\mathrm{HNO}_{3}$, shaken for 1 min, and then diluted with purified water. Dissolved $\mathrm{Fe}$ concentrations were determined by ICPMS (820-MS Varian, Australia) with hydrogen introduced into the collision reaction interface to reduce the interference of ${ }^{40} \mathrm{Ar}^{16} \mathrm{O}$ with ${ }^{56} \mathrm{Fe}$. As a check on the analytical method used to determine $\mathrm{DFe}$, SAFe reference materials were analysed in conjunction with samples (Johnson et al., 2007). The surface SAFe reference material was $0.09 \pm 0.02 \mathrm{nM}(n=4)$ and the deep SAFe 
reference material was $0.90 \pm 0.05 \mathrm{nM}(n=3)$, which are within the accepted ranges for these two reference materials $(0.097 \pm 0.043 \mathrm{nM}$ and $0.91 \pm 0.17 \mathrm{nM}$, respectively).

\section{Results}

\subsection{Biogeochemical setting}

The annual spring bloom off the eastern seaboard of New Zealand's North Island was evident from satellite remotesensing in September 2008 (Boyd et al., 2012), as was reported from Ocean Color satellite archives in previous years (Murphy et al., 2001). This bloom was sampled intensively during FeCycle II, and results presented in two overviews of this study (Boyd et al., 2012; Nodder et al., 2012) reveal that both the evolution (year days 261 to 269) and decline (269 to 272) of a diatom bloom were sampled. Physical oceanographic data indicate that the bloom was tracked in a quasi-Lagrangian manner between days 261 and 272 within the eddy centre (Nodder et al., 2012). After day 272, high winds $\left(>15 \mathrm{~m} \mathrm{~s}^{-1}\right)$ resulted in the drogued buoys exiting the eddy centre and moving counterclockwise around the periphery of the quiescent eddy center. The study must therefore be considered as two distinct phases - days 261 to 272 (within the eddy) and day 273 to 277 (outside the eddy and sampling occurred below the surface mixed layer).

In phase one, total chlorophyll reached a maximum of $\sim 1.7-2.6 \mu \mathrm{g} \mathrm{I}^{-1}$ on days 267 and 269 at both 30 and $60 \mathrm{~m}$, and the phytoplankton community was numerically dominated by diatoms (Asterionellopsis glacialis; up to $\sim 89$ cells $\mathrm{ml}^{-1}$ ) (Table 1). Chlorophyll declined in phase two likely due to Fe limitation (Boyd et al., 2012), during which the community was primarily composed of picoplankton. During days 266-270, chlorophyll at both 30 and $60 \mathrm{~m}$ in the $0.2-2,2-5,5-20$, and $>20 \mu \mathrm{m}$ size fractions accounted for $24 \pm 20 \%, 7 \pm 4 \%, 21 \pm 7 \%$, and $48 \pm 14 \%$ of total chlorophyll, respectively. After day 272, those respective fractions accounted for $46 \pm 11 \%, 23 \pm 9 \%, 17 \pm 4 \%$, and $14 \pm 8 \%$ of total chlorophyll.

POC, PON, POP, and BSi followed the same general pattern as chlorophyll with higher concentrations in phase one with maxima occurring on days 267 and $269(\sim 10 \mu \mathrm{M}$ POC, $\sim 2 \mu \mathrm{M}$ PON, $\sim 0.07 \mu \mathrm{M}$ POP, and $\sim 0.6 \mu \mathrm{M} \mathrm{BSi}$ ) (Table 2; Fig. 1a for POC). POC:POP ratios were initially $\sim 100-150$ (days 266-269), then increased to $\sim 190$ and $\sim 260$ on day 270 , at 30 and $60 \mathrm{~m}$ respectively, and then back down to $\sim 100$ to $\sim 120$ on days $273-278$. Over the entire study, POC:POP ratios averaged $127 \pm 28$ at $30 \mathrm{~m}$ and $139 \pm 55$ at $60 \mathrm{~m}$. Mean POC:PON ratios ranged from 4.4 to 8.6 with minima occurring on days $267(30 \mathrm{~m}), 272(30$ and $60 \mathrm{~m})$, and day 278 ( 30 and $60 \mathrm{~m}$ ) ranging from $\sim 4$ to 5. BSi:POP ratios were initially 7.3 to 11 (days 266-269), then increased to $\sim 15-20$ on day 270 (near the peak of the bloom phase), followed by a decline from days $272-279$ to $\sim 5$ (Table 2 ).
Total particulate $\mathrm{P}$ determined by ICPMS (P; i.e. oxalatewashed, all four size fractions summed) ranged from 11.8$47.1 \mathrm{nM}$ (30 m mean: $33.0 \pm 8.7 ; 60 \mathrm{~m}$ mean $23.8 \pm 7.8 \mathrm{nM}$ ) and was also higher during phase one with the highest values on day 267 and $269(\sim 44-47 \mathrm{nM}$ at $30 \mathrm{~m}$ and $\sim 25-35 \mathrm{nM}$ at $60 \mathrm{~m}$ ) (Fig. $1 \mathrm{~b}$ and Table 2 of the Supplement). The majority of $\mathrm{P}$ was in the $0.2-2 \mu \mathrm{m}$ size fraction for both depths, accounting for $59 \pm 7 \%$ of total P (Fig. $1 \mathrm{~b}$ and Table 2 of the Supplement). The $2-5 \mu \mathrm{m}$ and 5-20 $\mu \mathrm{m}$ fractions were each $<10 \%$ of total $\mathrm{P}$ while the $>20 \mu \mathrm{m}$ fraction was $25 \pm 10 \%$ of total P. The $>20 \mu \mathrm{m}$ fraction of $\mathrm{P}$ in the first phase of the study accounted for $\sim 22-45 \%$ of total $\mathrm{P}$, whereas the $>20 \mu \mathrm{m}$ fraction of $\mathrm{P}$ in the second phase accounted for $\sim 8$ $23 \%$ of total P. Oxalate-washed total P-values by ICPMS (four size fractions summed) at both 30 and $60 \mathrm{~m}$ were on average $37 \pm 15 \%$ lower than non-oxalate washed P determined using the colorimetric method for POP determination ( $\mathrm{P}: \mathrm{POP}=0.63$, linear regression $r^{2}=0.55$; data not shown). Oxalate-washed ICPMS-determined P was used for the calculation of ICPMS-based Fe:P quotas.

\section{$3.2{ }^{55} \mathrm{Fe}$ and ${ }^{14} \mathrm{C}$ radioisotope uptake}

Community ratios of $\mu \mathrm{mol} \mathrm{Fe}: \mathrm{molC}$ radioisotope uptake $(\mathrm{Fe}: \mathrm{C})$ derived from the ${ }^{55} \mathrm{Fe}$ and ${ }^{14} \mathrm{C}$ uptake experiments ranged from 4.0-14.2 (mean \pm 1 s.d.: $6.6 \pm 2.3$ ) and are shown in Fig. 2a and Table 3. Total Fe:C uptake ratios were lowest during the transition between the bloom phase and phase two of the study (on days 270 and 272, Fe:C uptake ratios ranged from 4.0-5.1). The lower Fe:C uptake ratios on days 270 and 272 were reflected in all four size fractions, and were a result of lower chlorophyll-normalized Fe uptake rates (Fig. $2 \mathrm{~b}$ and Table 3 of the Supplement). Fe:C uptake ratios were similar in waters collected from 30 and $60 \mathrm{~m}$ at most stations, with the exception of day 266 when total Fe:C uptake ratios in waters incubated from $30 \mathrm{~m}(14.2 \pm 2.6$, mean \pm 1 s.d.) were significantly higher than those from $60 \mathrm{~m}(5.7 \pm 1.7$, mean \pm 1 s.d.) (t-test; $p=0.0018)$ (Fig. 2a). Fe uptake rates from incubated samples collected at $30 \mathrm{~m}$ on day 266 were about two-fold higher than the average for the entire study (Fig. 2b and Table 3 of the Supplement). This resulted in significantly higher Fe:C uptake ratios in the total fraction and in each of the four size fractions in samples from this depth, compared to $60 \mathrm{~m}$ on this same day (t-test; $p<0.05$ ) (Table 3).

Generally, $\mathrm{Fe}: \mathrm{C}$ uptake ratios in each size fraction were relatively consistent with total $\mathrm{Fe}: \mathrm{C}$ uptake ratios (Table 3). In samples collected from $30 \mathrm{~m}$, the $\mathrm{Fe}: \mathrm{C}$ uptake ratio was $6.7 \pm 1.4$ in the $0.2-2 \mu \mathrm{m}$ fraction, $5.8 \pm 1.9$ in the $2-5 \mu \mathrm{m}$ fraction, $6.9 \pm 2.8$ in the $5-20 \mu \mathrm{m}$ fraction, and $6.3 \pm 1.7$ in the $>20 \mu \mathrm{m}$ fraction (excluding year day $266-30 \mathrm{~m}$ data). In samples collected from $60 \mathrm{~m}$, the mean total $\mathrm{Fe}: \mathrm{C}$ uptake ratio was $5.9 \pm 1.0$ and $\mathrm{Fe}: \mathrm{C}$ uptake ratio was $6.4 \pm 0.9$, $5.0 \pm 1.0,6.1 \pm 1.2$, and $5.7 \pm 1.6$ in the four size fractions, respectively. Excluding data from $30 \mathrm{~m}$ for year day 266, 
Table 2. Total and size fraction chl $\left(\mu \mathrm{g} \mathrm{chl} 1^{-1}\right)$, chl size frequency distribution (fraction of total), total non-oxalate washed $\mu \mathrm{M}$ PON, $\mu \mathrm{m}$ $\mathrm{BSi}$, and molar ratios of POC:POP, POC:PON, and BSi:POP for 30 and $60 \mathrm{~m}$ (mean \pm 1 standard deviation; $n=3$ ). Size fractions consisted of $0.2-2 \mu \mathrm{m}, 2-5 \mu \mathrm{m}, 5-20 \mu \mathrm{m}$, and $>20 \mu \mathrm{m}$; total represents the sum of all size fractions $(>0.2 \mu \mathrm{m})$.

\begin{tabular}{|c|c|c|c|c|c|c|c|c|c|c|c|c|c|c|c|c|c|c|c|c|}
\hline \multirow[b]{2}{*}{ depth } & \multirow[b]{2}{*}{ day } & \multicolumn{5}{|c|}{ chl } & \multicolumn{4}{|c|}{ fraction of total } & \multicolumn{2}{|c|}{ PON } & \multicolumn{2}{|c|}{$\mathrm{BSi}$} & \multicolumn{2}{|c|}{ POC:POP } & \multicolumn{2}{|c|}{ POC:PON } & \multicolumn{2}{|c|}{ BSi:POP } \\
\hline & & $0.2-2$ & $2-5$ & $5-20$ & $>20$ & total & $0.2-2$ & $2-5$ & $5-20$ & $>20$ & mean & sd & mean & sd & mean & sd & mean & sd & mean & sd \\
\hline \multirow[t]{10}{*}{30} & 266 & 0.38 & 0.14 & 0.22 & 0.50 & 1.2 & 0.31 & 0.11 & 0.17 & 0.40 & 0.76 & 0.00 & 0.40 & 0.02 & 105 & 7 & 6.9 & 0.2 & 8.0 & 0.3 \\
\hline & 267 & 0.27 & 0.05 & 0.47 & 0.93 & 1.7 & 0.16 & 0.03 & 0.27 & 0.54 & 1.88 & 0.56 & 0.62 & 0.02 & 115 & 3 & 4.0 & 1.4 & 9.5 & 0.7 \\
\hline & 269 & 0.29 & 0.15 & 0.42 & 0.54 & 1.4 & 0.21 & 0.11 & 0.30 & 0.39 & 1.46 & 0.15 & 0.51 & 0.05 & 136 & 17 & 6.7 & 0.5 & 7.2 & 1.7 \\
\hline & 270 & 0.10 & 0.13 & 0.20 & 0.62 & 1.1 & 0.10 & 0.12 & 0.19 & 0.59 & 1.11 & 0.05 & 0.50 & 0.03 & 189 & 31 & 6.1 & 0.5 & 13.9 & 3.1 \\
\hline & 272 & 0.51 & 0.27 & 0.10 & 0.06 & 0.9 & 0.54 & 0.28 & 0.11 & 0.07 & 1.25 & 0.11 & 0.28 & 0.04 & 108 & 7 & 4.6 & 0.4 & 5.3 & 0.8 \\
\hline & 273 & 0.27 & 0.17 & 0.16 & 0.13 & 0.7 & 0.37 & 0.23 & 0.22 & 0.18 & 0.79 & 0.31 & 0.27 & 0.03 & 124 & 16 & 6.8 & 2.0 & 6.2 & 0.6 \\
\hline & 275 & 0.51 & 0.27 & 0.17 & 0.06 & 1.0 & 0.50 & 0.27 & 0.17 & 0.06 & 0.76 & 0.16 & 0.19 & 0.01 & 114 & 13 & 6.7 & 1.1 & 4.3 & 0.3 \\
\hline & 278 & 0.77 & 0.25 & 0.26 & 0.24 & 1.5 & 0.50 & 0.17 & 0.17 & 0.16 & 1.40 & 0.53 & 0.22 & 0.03 & 123 & 9 & 4.2 & 1.8 & 4.7 & 0.7 \\
\hline & mean & 0.39 & 0.18 & 0.25 & 0.39 & 1.2 & 0.34 & 0.16 & 0.20 & 0.30 & 1.18 & & 0.4 & & 127 & & 5.7 & & 7.4 & \\
\hline & sd & 0.20 & 0.08 & 0.13 & 0.31 & 0.3 & 0.17 & 0.09 & 0.06 & 0.21 & 0.40 & & 0.2 & & 27 & & 1.3 & & 3.2 & \\
\hline \multirow[t]{10}{*}{60} & 266 & 1.85 & 0.10 & 0.20 & 0.52 & 2.7 & 0.69 & 0.04 & 0.08 & 0.19 & 0.86 & 0.10 & 0.47 & 0.05 & 112 & 12 & 6.9 & 1.0 & 8.8 & 0.6 \\
\hline & 267 & 0.55 & 0.02 & 0.36 & 1.00 & 1.9 & 0.28 & 0.01 & 0.19 & 0.52 & 1.43 & 1.07 & 0.52 & 0.06 & 122 & 48 & 4.4 & 2.1 & 10.0 & 0.7 \\
\hline & 269 & 0.10 & 0.06 & 0.19 & 0.62 & 1.0 & 0.10 & 0.07 & 0.19 & 0.64 & 0.44 & 0.05 & 0.40 & 0.04 & 104 & 5 & 8.6 & 1.3 & 10.9 & 1.1 \\
\hline & 270 & 0.06 & 0.10 & 0.28 & 0.59 & 1.0 & 0.06 & 0.10 & 0.27 & 0.57 & 0.96 & 0.18 & 0.46 & 0.03 & 262 & 27 & 6.2 & 1.0 & 19.8 & 1.9 \\
\hline & 272 & 0.30 & 0.10 & 0.13 & 0.15 & 0.7 & 0.44 & 0.15 & 0.20 & 0.22 & 1.22 & 0.15 & 0.23 & 0.01 & 179 & 82 & 4.5 & 1.4 & 7.4 & 3.0 \\
\hline & 273 & 0.78 & 0.24 & 0.19 & 0.14 & 1.3 & 0.58 & 0.18 & 0.14 & 0.10 & 0.86 & 0.19 & 0.22 & 0.01 & 113 & 14 & 6.2 & 0.8 & 4.6 & 0.2 \\
\hline & 275 & 0.48 & 0.28 & 0.14 & 0.06 & 1.0 & 0.50 & 0.29 & 0.14 & 0.06 & 0.70 & 0.05 & 0.21 & 0.02 & 101 & 6 & 6.3 & 0.3 & 4.7 & 0.5 \\
\hline & 278 & 0.24 & 0.26 & 0.19 & 0.28 & 1.0 & 0.25 & 0.26 & 0.20 & 0.29 & 1.10 & 0.62 & 0.18 & 0.02 & 121 & 4 & 3.7 & 2.2 & 5.5 & 0.4 \\
\hline & mean & 0.54 & 0.15 & 0.21 & 0.42 & 1.3 & 0.36 & 0.14 & 0.18 & 0.32 & 0.95 & & 0.3 & & 139 & & 5.9 & & 9.0 & \\
\hline & sd & 0.58 & 0.10 & 0.08 & 0.32 & 0.7 & 0.23 & 0.10 & 0.06 & 0.22 & 0.31 & & 0.1 & & 55 & & 1.6 & & 5.0 & \\
\hline \multirow[t]{2}{*}{30 and 60} & mean & 0.46 & 0.16 & 0.23 & 0.40 & 1.3 & 0.35 & 0.15 & 0.19 & 0.31 & 1.07 & & 0.36 & & 133 & & 5.8 & & 8.1 & \\
\hline & $\mathrm{sd}$ & 0.41 & 0.09 & 0.10 & 0.30 & 0.5 & 0.19 & 0.09 & 0.06 & 0.20 & 0.35 & & 0.14 & & 41 & & 1.3 & & 4.0 & \\
\hline
\end{tabular}

Table 3. Total and size fraction Fe:C ( $\mu$ mol:mol) based on Fe and $\mathrm{C}$ uptake, oxalate washed and ICPMS-determined size fraction BFe:P (mmol:mol), and total BFe:POC ( $\mu \mathrm{mol}: \mathrm{mol})$ for samples collected at 30 and $60 \mathrm{~m}$ (mean \pm 1 standard deviation; $n=3)$.

\begin{tabular}{|c|c|c|c|c|c|c|c|c|c|c|c|c|c|c|c|c|c|c|c|c|c|c|c|}
\hline \multirow[b]{3}{*}{ depth } & \multirow[b]{3}{*}{ day } & \multicolumn{10}{|c|}{$\mathrm{Fe}: \mathrm{C}$ uptake } & \multicolumn{10}{|c|}{ BFe:P } & \multirow{2}{*}{\multicolumn{2}{|c|}{$\begin{array}{c}\text { BFe:POC } \\
\text { total }\end{array}$}} \\
\hline & & \multicolumn{2}{|c|}{$0.2-2 \mu \mathrm{m}$} & \multicolumn{2}{|c|}{$2-5 \mu \mathrm{m}$} & \multicolumn{2}{|c|}{$5-20 \mu \mathrm{m}$} & \multicolumn{2}{|c|}{$>20 \mu \mathrm{m}$} & \multicolumn{2}{|c|}{ total } & \multicolumn{2}{|c|}{$0.2-2 \mu \mathrm{m}$} & \multicolumn{2}{|c|}{$2-5 \mu \mathrm{m}$} & \multicolumn{2}{|c|}{$5-20 \mu \mathrm{m}$} & \multicolumn{2}{|c|}{$>20 \mu \mathrm{m}$} & \multicolumn{2}{|c|}{ total } & & \\
\hline & & mean & $\mathrm{sd}$ & mean & sd & mean & sd & mean & sd & mean & sd & mean & sd & mean & $\mathrm{sd}$ & mean & $\mathrm{sd}$ & mean & $\mathrm{sd}$ & mean & $\mathrm{sd}$ & mean & sd \\
\hline \multirow[t]{10}{*}{30} & 266 & 14.0 & 1.5 & 13.5 & 7.3 & 16.1 & 8.9 & 13.6 & 7.0 & 14.2 & 2.6 & 24.6 & 9.3 & 20.7 & 17.0 & 60.7 & 24.4 & 1.4 & 2.4 & 20.6 & 5.4 & 113 & 7 \\
\hline & 267 & 6.5 & 1.2 & 6.0 & 1.3 & 5.7 & 6.6 & 5.3 & 2.1 & 5.8 & 1.2 & 6.9 & 1.1 & 56.1 & 7.6 & 12.1 & 20.9 & $\mathrm{a}$ & $\mathrm{a}$ & 6.2 & 1.3 & 40 & 14 \\
\hline & 269 & 7.4 & 2.5 & 5.2 & 1.7 & 7.2 & 2.0 & 7.9 & 1.5 & 7.0 & 1.3 & 10.1 & 0.4 & a & $\mathrm{a}$ & 63.7 & 34.1 & 1.7 & 2.5 & 12.7 & 3.5 & 56 & 13 \\
\hline & 270 & 4.6 & 1.5 & 4.2 & 0.5 & 4.4 & 2.1 & 5.4 & 2.2 & 4.7 & 0.9 & 9.5 & 8.5 & $\mathrm{a}$ & $\mathrm{a}$ & 50.0 & 1.4 & $\mathrm{a}$ & $\mathrm{a}$ & 9.0 & 3.0 & 31 & 11 \\
\hline & 272 & 4.7 & 1.4 & 5.9 & 2.1 & 4.9 & 2.4 & 3.4 & 3.9 & 5.1 & 1.1 & 11.1 & 6.8 & 87.8 & 57.2 & 16.2 & 16.2 & $\mathrm{a}$ & $\mathrm{a}$ & 15.2 & 6.3 & 66 & 25 \\
\hline & 273 & 7.9 & 1.1 & 7.1 & 2.1 & 11.2 & 3.2 & 8.0 & 1.3 & 8.0 & 1.2 & 4.3 & 3.9 & 3.0 & 5.2 & 14.5 & 15.8 & 1.2 & 2.0 & 4.8 & 1.8 & 23 & 8 \\
\hline & 275 & 8.1 & 2.8 & 6.3 & 2.5 & 7.9 & 0.5 & 7.3 & 2.3 & 7.4 & 1.4 & 12.0 & 6.6 & 70.8 & 33.3 & 17.6 & 10.4 & 26.8 & 33.2 & 19.8 & 8.6 & 136 & 71 \\
\hline & 278 & 7.2 & 1.4 & 6.1 & 0.8 & 6.9 & 2.9 & 6.8 & 4.3 & 6.8 & 0.9 & 1.8 & 2.7 & 0.3 & 0.4 & 19.5 & 17.9 & $\mathrm{a}$ & $\mathrm{a}$ & 2.7 & 2.3 & 16 & 16 \\
\hline & mean & 7.6 & & 6.8 & & 8.0 & & 7.2 & & 7.4 & & 10.0 & & 39.8 & & 31.8 & & 7.8 & & 11.4 & & 60 & \\
\hline & sd & 2.9 & & 2.8 & & 3.9 & & 3.0 & & 3.0 & & 6.9 & & 36.9 & & 22.3 & & 12.7 & & 6.8 & & 43 & \\
\hline \multirow[t]{10}{*}{60} & 266 & 6.5 & 1.3 & 4.6 & 1.7 & 5.6 & 3.4 & 5.4 & 3.7 & 5.7 & 1.7 & 25.9 & 7.0 & 24.1 & 18.1 & 36.1 & 30.5 & $\mathrm{a}$ & $\mathrm{a}$ & 15.9 & 1.2 & 74 & 15 \\
\hline & 267 & 6.5 & 2.4 & 5.3 & 1.7 & 6.5 & 1.5 & 5.8 & 1.5 & 6.0 & 1.0 & 16.6 & 3.1 & 32.9 & 29.2 & 22.5 & 20.1 & $\mathrm{a}$ & a & 10.5 & 2.6 & 48 & 14 \\
\hline & 269 & 6.5 & 0.9 & 5.6 & 1.1 & 5.3 & 4.6 & 7.1 & 0.7 & 6.3 & 0.9 & 10.6 & 1.3 & 16.9 & 11.6 & a & $\mathrm{a}$ & a & a & 6.9 & 1.2 & 44 & 5 \\
\hline & 270 & 5.2 & 1.1 & 3.3 & 0.4 & 4.7 & 1.6 & 2.9 & 3.0 & 4.0 & 1.2 & 3.8 & 5.4 & 237 & 64.8 & 73.6 & 45.5 & $\mathrm{a}$ & $\mathrm{a}$ & 14.9 & 10.2 & 52 & 36 \\
\hline & 272 & 5.0 & 0.6 & 4.0 & 1.1 & 4.7 & 1.3 & 6.5 & 0.7 & 5.0 & 0.4 & 19.1 & 4.8 & 18.1 & 2.9 & 50.6 & 15.6 & $\mathrm{a}$ & a & 17.3 & 3.6 & 58 & 8 \\
\hline & 273 & 6.6 & 2.5 & 5.1 & 1.4 & 7.4 & 3.6 & 6.7 & 4.0 & 6.4 & 1.4 & 1.1 & 2.0 & 40.7 & 70.4 & 7.3 & 12.7 & a & a & 2.9 & 3.5 & 6 & 8 \\
\hline & 275 & 7.6 & 2.6 & 5.6 & 2.9 & 8.0 & 2.4 & 7.2 & 2.2 & 6.9 & 1.6 & 5.3 & 0.7 & 1.1 & 0.8 & 56.5 & 42.7 & 8.2 & 8.2 & 12.0 & 6.5 & 84 & 44 \\
\hline & 278 & 7.4 & 1.8 & 6.5 & 3.6 & 6.4 & 3.4 & 3.7 & 1.9 & 6.8 & 1.5 & 0.5 & 0.1 & $\mathrm{a}$ & $\mathrm{a}$ & 4.4 & 2.2 & 1.3 & 2.3 & 0.8 & 0.3 & 4 & 2 \\
\hline & mean & 6.4 & & 5.0 & & 6.1 & & 5.7 & & 5.9 & & 10.3 & & 53.0 & & 35.9 & 4.8 & & 10.1 & & 46 & & \\
\hline & sd & 0.9 & & 1.0 & & 1.2 & & 1.6 & & 1.0 & & 9.3 & & 82.1 & & 26.0 & & 4.8 & & 6.1 & & 29 & \\
\hline \multirow[t]{2}{*}{30 and 60} & mean & 7.0 & & 5.9 & & 7.1 & & 6.4 & & 6.6 & & 10.2 & & 46.9 & & 33.7 & & 6.8 & & 10.8 & & 53.3 & \\
\hline & sd & 2.2 & & 2.3 & & 3.0 & & 2.5 & & 2.3 & & 7.9 & & 63.1 & & 23.3 & & 10.2 & & 6.3 & & 36.1 & \\
\hline
\end{tabular}

$\mathrm{a}=$ zero or negative value. 
total Fe:C uptake ratios in incubated samples collected from $30 \mathrm{~m}$ and $60 \mathrm{~m}$ were $6.4 \pm 1.2$ and $5.9 \pm 1.0$, respectively. Although chlorophyll-normalized ${ }^{55} \mathrm{Fe}$ and ${ }^{14} \mathrm{C}$ uptake rates varied between depths and days, the normalized uptake rates were positively correlated due to $\mathrm{Fe}$ and $\mathrm{C}$ uptake scaling with each other, resulting in relatively low variability in $\mathrm{Fe}: \mathrm{C}$ uptake ratios $\left(r^{2}=0.75, p<0.01\right)$.

\subsection{ICPMS Fe quotas}

Total mmol biogenic $\mathrm{Fe}(\mathrm{BFe})$ :mol $\mathrm{P}$ ratios ranged from $0.7-$ 20.1 , with mean ratios of $11.4 \pm 6.8$ and $10.1 \pm 6.3$ at 30 and $60 \mathrm{~m}$, respectively (Fig. 3a, Table 3). From both depths, $\mathrm{BFe}: \mathrm{P}$ ratios averaged $10,47,34$, and 7 from the $0.2-$ $2 \mu \mathrm{m}, 2-5 \mu \mathrm{m}, 5-20 \mu \mathrm{m}$, and $>20 \mu \mathrm{m}$ size fractions, respectively (Table 3 ). Total $\mu \mathrm{mol}$ BFe:mol POC ratios (BFe:POC) ranged from 4-136, with mean ratios of $60 \pm 43$ and $46 \pm 29$ at 30 and $60 \mathrm{~m}$, respectively (Fig. 3b; Table 3). The lowest $\mathrm{BFe}$ quotas observed were in phase two of the study on days 273 and 278 (0.8-4.8 BFe:P; 4-23 BFe:POC; t-test; not significant). The low $\mathrm{BFe}$ quotas during on days 273 and 278 were driven by lower $\mathrm{BFe}$, not higher $\mathrm{POC}$ and $\mathrm{P}$ values, since the latter were comparable to or lower than values measured on other days. In addition, on these days (273 and 278), BFe in each size fraction was below the calculated average $\mathrm{BFe}$ for the entire study. BFe:P ratios were significantly higher at $30 \mathrm{~m}$ compared to $60 \mathrm{~m}$ on days $266,267,269$, and 278 (t-test; $p<0.05 ; 60 \mathrm{~m}$ sample on day 269 was from below the surface mixed layer) (Fig. 3a). BFe:POC ratios were only significantly higher at $30 \mathrm{~m}$ compared to $60 \mathrm{~m}$ on day 266 (t-test; $p<0.05$ ) (Fig. 3b).

On average over all eight days sampled, the distribution of total particulate $\mathrm{Fe}(\mathrm{PFe})$ by size at 30 and $60 \mathrm{~m}$ were comparable, averaging $29 \pm 6 \%, 12 \pm 10 \%, 37 \pm 16 \%$, and $24 \pm 9 \%$ of total PFe in the $0.2-2 \mu \mathrm{m}, 2-5 \mu \mathrm{m}, 5-20 \mu \mathrm{m}$, and $>20 \mu \mathrm{m}$ fractions, respectively (Fig. $4 \mathrm{a}$ and Table 4 of the Supplement). Total PAl, on the other hand, was mostly found in the $>20 \mu \mathrm{m}$ fraction, comprising $57 \pm 10 \%$ of total PAl at $30 \mathrm{~m}$ and $46 \pm 11 \%$ at $60 \mathrm{~m}$ (Fig. $4 \mathrm{~b}$ and Table 4 of the Supplement). PAl combined in the $0.2-2 \mu \mathrm{m}$ and $2-5 \mu \mathrm{m}$ fractions at both $30 \mathrm{~m}$ and $60 \mathrm{~m}$ accounted for $<20 \%$ of total PAl. Lithogenic Fe (calculated from PAl using a $0.18 \mathrm{Fe}: \mathrm{Al}$ molar ratio; Frew et al., 2006) accounted for $40-92 \%$ of PFe (Fig. 4c). Total BFe (the difference between PFe and calculated $\mathrm{LFe}$ ) at $30 \mathrm{~m}$ and $60 \mathrm{~m}$ ranged from $0.02-0.66 \mathrm{nM}(30$ mean: $0.36 \pm 0.22 \mathrm{nM} ; 60 \mathrm{~m}$ mean: $0.25 \pm 0.16 \mathrm{nM}$ ) (Fig. $4 \mathrm{~d}$ and Table 4 of the Supplement). In some cases, calculated $\mathrm{LFe}$ concentrations were equivalent to $\mathrm{PFe}$, resulting in zero or even negative values for $\mathrm{BFe}$ within certain size fractions and days (Supplement; Table 4). By size fraction, LFe on average accounted for $\sim 40 \%, 69 \%, 80 \%$, and $>96 \%$ of $\mathrm{PFe}$ in the $0.2-2 \mu \mathrm{m}, 2-5 \mu \mathrm{m}, 5-20 \mu \mathrm{m}$, and $>20 \mu \mathrm{m}$ fractions, respectively. The large contribution of the $>20 \mu \mathrm{m}$ fraction $\mathrm{LFe}$ to total $\mathrm{LFe}$ resulted in a marked shift in $\mathrm{BFe}$ towards smaller size fractions, with the $0.2-2 \mu \mathrm{m}$ fraction ac-
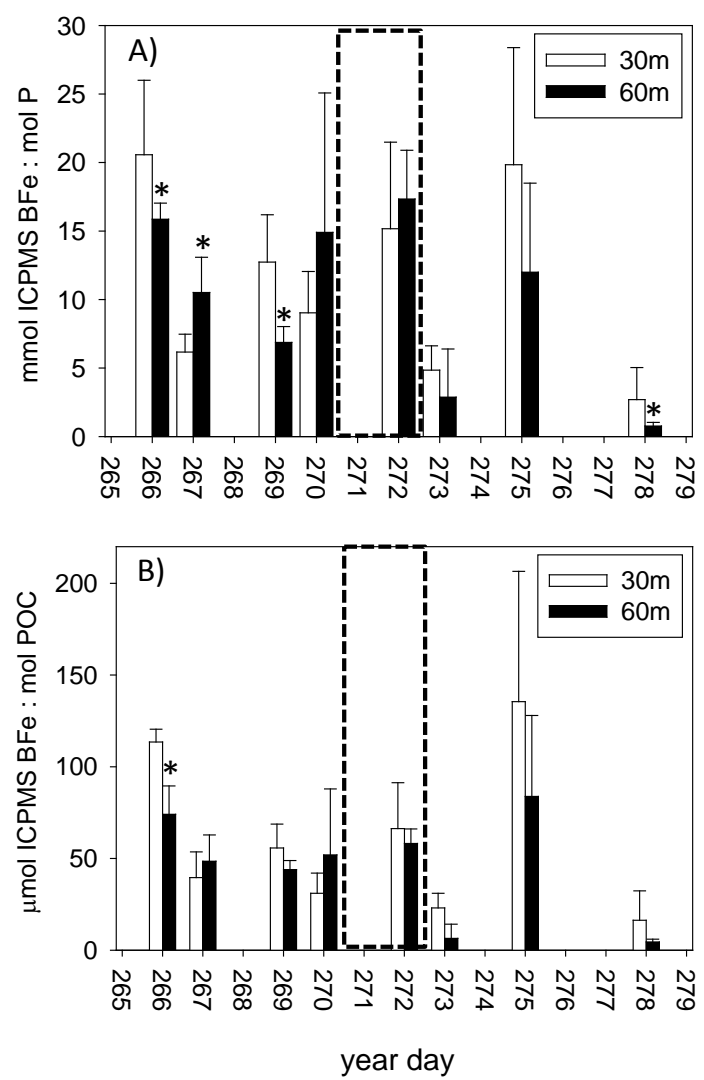

Fig. 3. Oxalate-washed ICPMS-based BFe:P and BFe:POC ratios at $30 \mathrm{~m}$ and $60 \mathrm{~m}$ over the course of the study. (A) mmol BFe:mol P and (B) $\mu \mathrm{mol}$ BFe:mol POC. For each day, left bar (white) $=30 \mathrm{~m}$, right bar (black) $=60 \mathrm{~m}$. The transition between the two phases of the study is marked by the dashed line rectangle. Error bars represent 1 standard deviation $(n=3)$. Significant differences between 30 and $60 \mathrm{~m}$ is designated by an asterisk $(p<0.05)$.

counting for about half of total (Fig. $4 \mathrm{~d}$ and Table 4 of the Supplement).

\subsection{SXRF Fe quotas}

One hundred thirty-one cells collected from the water column over seven days were analyzed with SXRF for Fe and $\mathrm{P}$ (Table 4). These cells were grouped into four taxonomic classes: autotrophic flagellates, autotrophic picoplankton, Asterionellopsis glacialis, and "other diatoms" (mostly centrics with a few pennates). The number of cells from each group analyzed on each day was constrained by the available cells mounted on the grids, potentially resulting in a skewed dataset. More than 40 individual autotrophic flagellates and autotrophic picoplankton were analyzed, including 4 days when at least 5 autotrophic flagellates and 10 autotrophic picoplankton cells were analyzed. In contrast, only 13 "other diatoms" were analyzed in total (between 1 and 3 per day). Given the unique nature of the data 
Table 4. Number of cells analyzed by SXRF by date and cell type (Aflag = autotrophic flagellates, Asterio=Asterionellopsis glacialis, Apico $=$ autotrophic picoplankton, other $=$ other diatoms) and LS mean Fe:P (mmol:mol), LS mean Fe:C biovol ( $\mu$ mol:mol; $\mathrm{C}$ calculated using biovolume estimates), and LS mean Fe:C ( $\mu$ mol:mol; C converted using $133 \mathrm{~mol} \mathrm{C}: \mathrm{mol} \mathrm{P})( \pm$ standard error; se) calculated for each year day.

\begin{tabular}{|c|c|c|c|c|c|c|c|c|c|c|c|}
\hline \multirow[b]{2}{*}{ day } & \multirow[b]{2}{*}{ total cells } & \multirow[b]{2}{*}{ Aflag } & \multirow[b]{2}{*}{ Asterio } & \multirow[b]{2}{*}{ Apico } & \multirow[b]{2}{*}{ other } & \multicolumn{2}{|c|}{ Fe:P } & \multicolumn{2}{|c|}{ Fe:C biovol. } & \multicolumn{2}{|c|}{ Fe:C conv. } \\
\hline & & & & & & mean & se & mean & se & mean & se \\
\hline 263 & 9 & 0 & 7 & 0 & 2 & 5.0 & 1.5 & 40 & 15 & 38 & 11 \\
\hline 264 & 6 & 0 & 6 & 0 & 0 & 7.5 & 2.8 & 57 & 28 & 56 & 21 \\
\hline 266 & 37 & 6 & 2 & 26 & 3 & 4.5 & 0.8 & 14 & 3 & 34 & 6 \\
\hline 267 & 27 & 12 & 0 & 14 & 1 & 3.9 & 0.7 & 17 & 4 & 29 & 5 \\
\hline 272 & 22 & 9 & 0 & 10 & 3 & 2.3 & 0.4 & 11 & 3 & 17 & 3 \\
\hline 273 & 4 & 2 & 0 & 0 & 2 & 3.2 & 1.4 & 25 & 14 & 24 & 11 \\
\hline 278 & 26 & 11 & 0 & 13 & 2 & 4.8 & 0.9 & 13 & 3 & 36 & 7 \\
\hline TOTAL & 131 & 40 & 15 & 63 & 13 & & & & & & \\
\hline
\end{tabular}

we have decided to include these cells in the dataset, while recognizing the limitations imposed by the small sample size.

An ANCOVA model was used to test for significant effects of time (sampling day), depth, cell biovolume, and cell taxonomy on the Fe:P ratios of phytoplankton cells collected over the course of the bloom. Only time $(p=0.004)$ and taxonomic grouping $(p=0.03)$ were statistically significant effects; cellular Fe:P ratios were not significantly different between cells collected at different depths ( $p=$ $0.19)$ or between cells of varying biovolume $(p=0.1541)$. Standardizing over the time course of the bloom, LS mean Fe:P ratios were calculated for each day and are presented in Table 4. P-normalized Fe quotas were highest in nonAsterionellopsis diatoms $(7.2 \pm 1.6 \mathrm{mmol}: \mathrm{mol})$ and lowest in A. glacialis $(2.7 \pm 1.1 \mathrm{mmol}: \mathrm{mol})$. Fe:P ratios of non-diatoms fell in the middle of this range (autotrophic flagellates: $3.9 \pm 0.7 \mathrm{mmol}: \mathrm{mol}$; autotrophic picoplankton: $4.7 \pm 0.9 \mathrm{mmol}: \mathrm{mol}$ ) (Table 5).

In order to facilitate comparisons of the SXRF single cell data with size-fractionated ICPMS and radioisotope data, the cells were also grouped into matching size classes according to their longest dimension as measured with light microscopy following the voyage. These size groupings approximate to the taxonomic groups, as the $0.2-2 \mu \mathrm{m}$ class was entirely comprised of autotrophic picoplankton, the $2-5 \mu \mathrm{m}$ class was comprised of the autotrophic flagellates and one unidentified centric diatom, the 5-20 $\mu \mathrm{m}$ class was comprised of 3 of the larger autotrophic flagellates and 8 centrics, and the $>20 \mu \mathrm{m}$ class was mostly Asterionellopsis and several of the larger diatoms. A separate ANCOVA was used to test for significant effects of time (sampling day), depth, cell biovolume, and cell-size category on the Fe:P ratios of phytoplankton cells collected over the course of the bloom. Again, sampling day and cell-size grouping were the only significant effects ( $p=0.0063$ and $p=0.0171$, respectively). LS mean
Fe:P ratios for the four size classes were $4.4 \pm 0.9,3.5 \pm 0.6$, $7.5 \pm 1.7$, and $2.7 \pm 1.1$ for $0.2-2,2-5,5-20$ and $>20 \mu \mathrm{m}$, respectively (Table 5). LS mean Fe:P values for each sampling date were also calculated by the ANCOVA. There was a significant $(p=0.0063)$ drop in Fe:P from the beginning of the patch sampling $(5.0 \mathrm{mmol}: \mathrm{mol})$ to the period immediately following the bloom $(2.3 \mathrm{mmol}: \mathrm{mol})$; Fe:P then increased back to $\sim 4.8 \mathrm{mmol}$ :mol by the end of FeCycle II (Table 4). Because SXRF does not detect C, Fe:C ratios were determined using biovolume-based calculations or bulk $\mathrm{C}: \mathrm{P}$ conversions (see Discussion).

\section{Discussion}

\subsection{Inter-technique comparisons}

We assessed the three techniques used for estimating total $\mathrm{Fe}$ quota by comparing P- and C-based quotas (Fig. 5). Both P and $\mathrm{C}$ normalizations were used because although all three approaches measured Fe uptake or content, the bulk filtration technique (Fe determined by ICPMS) included complementary direct measurements of both bulk $\mathrm{P}$ and $\mathrm{C}(\mathrm{P}$ was measured from the $>0.2 \mu \mathrm{m}$ size fraction; POC samples were $>0.7 \mu \mathrm{m}$ ), while the radioisotope uptake and SXRFbased techniques only had direct measurements of $\mathrm{C}$ uptake and cellular P content, respectively. The Fe:P-based comparison (Fig. 5a) consists of: (1) oxalate-washed total Fe:C radioisotope uptake converted to $\mathrm{Fe}: \mathrm{P}$ uptake using a $\mathrm{C}: \mathrm{P}$ ratio of 133:1 (the average POC:POP ratio from the study period), (2) oxalate-washed total ICPMS-determined BFe:P, and (3) SXRF-determined Fe:P. The Fe:C-based comparison (Fig. 5b) consists of: (1) oxalate-washed total $\mathrm{Fe}$ :C radioisotope uptake, (2) oxalate-washed total ICPMS-determined $\mathrm{BFe}: \mathrm{POC}$ (POC was derived from gas chromatography and not oxalate-washed), and (3) SXRF-determined Fe and C 

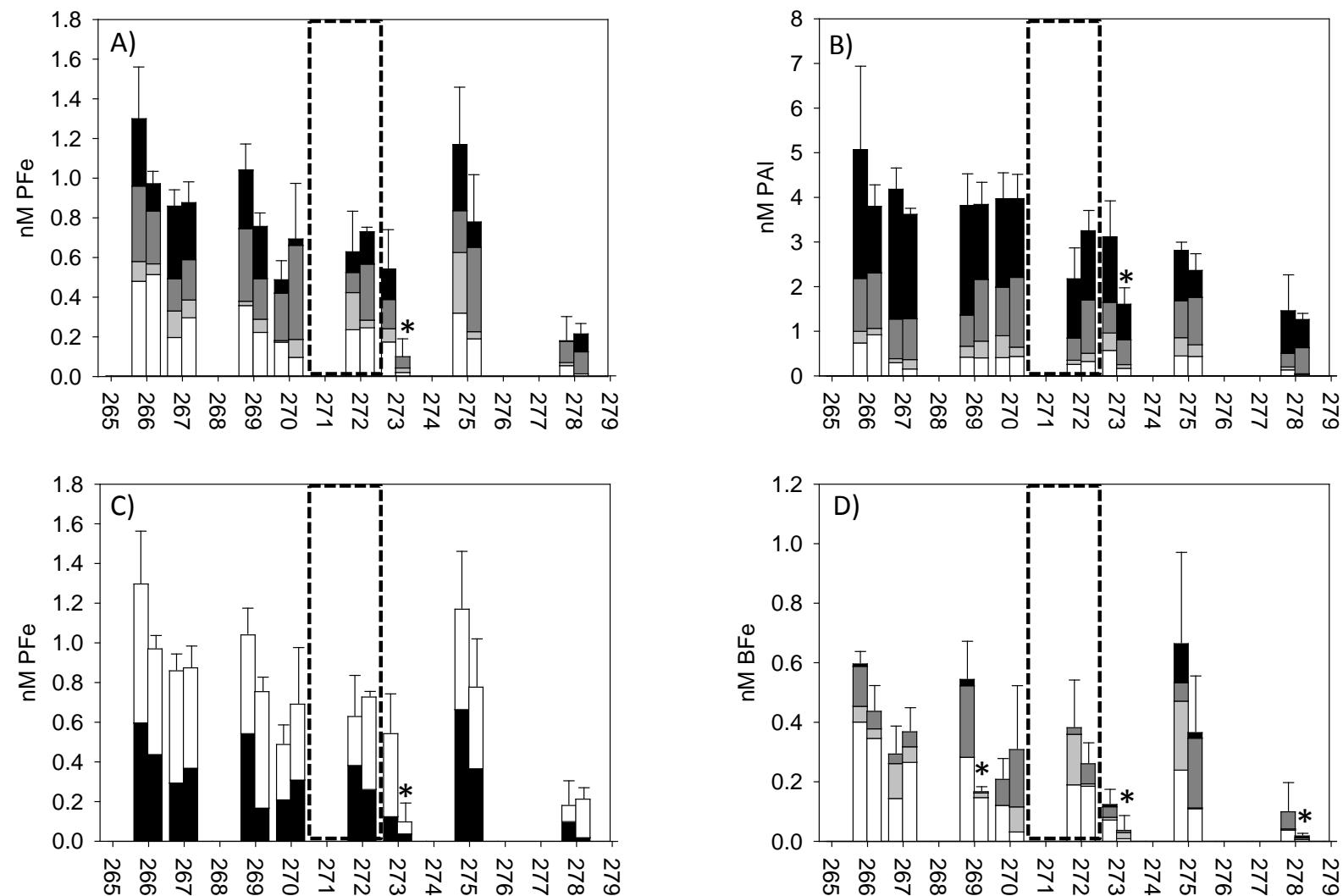

year day

Fig. 4. ICPMS-based particulate $\mathrm{Fe}(\mathrm{PFe})$, particulate $\mathrm{Al}(\mathrm{PAl})$, and calculated biogenic $\mathrm{Fe}(\mathrm{BFe})$ concentrations at 30 and $60 \mathrm{~m}$ over the course of the experiment. (A) Total nM PFe and stacked by size fraction, (B) total nM PAl and stacked by size fraction, (C) total nM PFe with lithogenic $\mathrm{Fe}(\mathrm{LFe})$ stacked on top of biogenic $\mathrm{Fe}(\mathrm{BFe})$, and (D) total nM BFe and stacked by size fraction. Stacked data represent (top to bottom) the $>20 \mu \mathrm{m}, 5-20 \mu \mathrm{m}, 2-5 \mu \mathrm{m}$, and $0.2-2 \mu \mathrm{m}$ fractions. For each day, left bar $=30 \mathrm{~m}$, right bar $=60 \mathrm{~m}$. The transition between the two phases of the study is marked by the dashed line rectangle. Error bars represent 1 standard deviation $(n=3)$. Significant differences between $30 \mathrm{~m}$ and $60 \mathrm{~m}$ total values designated by asterisk $(p<0.05)$.

calculated by two methods: using biovolume estimates and conversion of SXRF-determined P using a C:P ratio of 133:1.

Estimated Fe quotas varied between the three techniques and over time. The lowest Fe quotas were from radioisotope uptake, with the exception of the $30 \mathrm{~m}$ sample from day 266 (Fig. 5). The next highest ratios were from the SXRFbased $\mathrm{Fe}: \mathrm{P}$ and $\mathrm{Fe}: \mathrm{C}$ (converted) which were 2.5-6.2 times greater than radioisotope uptake-based quotas, while SXRF $\mathrm{Fe}: \mathrm{C}$ (biovolume) were 1.0-4.2 times greater than radioisotope uptake. The highest Fe quotas, and also the most variable, were from the ICPMS-based technique in which Fe:C and Fe:P ratios were up to $\sim 10-15$ times higher than the radioisotope-based. Despite this, there were several days when ICPMS-determined Fe quotas were comparable to both radioisotope and SXRF-based measurements (e.g. day 273 and 278) (Fig. 5).
Temporally, changes in Fe quotas somewhat reflected the variability observed in phytoplankton community structure and the evolution and decline in a diatom spring bloom. $\mathrm{Fe}$ quotas from radioisotope uptake and SXRF methods decreased on days 270 and 272 at the end of the spring bloom, likely due to the decrease in DFe availability (Boyd et al., 2012). This decrease occurred concomitantly with decreases in total chlorophyll and chlorophyll in the $>20 \mu \mathrm{m}$ size fraction, the peak and decline of the ratio of BSi:POP, and declines in dissolved macronutrients and $\mathrm{Fe}$ (Table 1; on day 272 , nitrate was $\sim 0.5 \mu \mathrm{M}$, phosphate was $\sim 0.2 \mu \mathrm{M}$, silicic acid was $\sim 0.7 \mu \mathrm{M}$, and $\mathrm{dFe}$ was $<0.1 \mathrm{nM}$; Ellwood et al., 2012). The decline in radioisotope uptake- and SXRFbased $\mathrm{Fe}$ quotas on days 270 and 272 was not reflected in Fe quotas determined by ICPMS. The two occasions when ICMPS-determined $\mathrm{Fe}$ quotas converged with radioisotope and SXRF-based quotas was after the high wind event (day 273) and in the second phase at the study at which point 

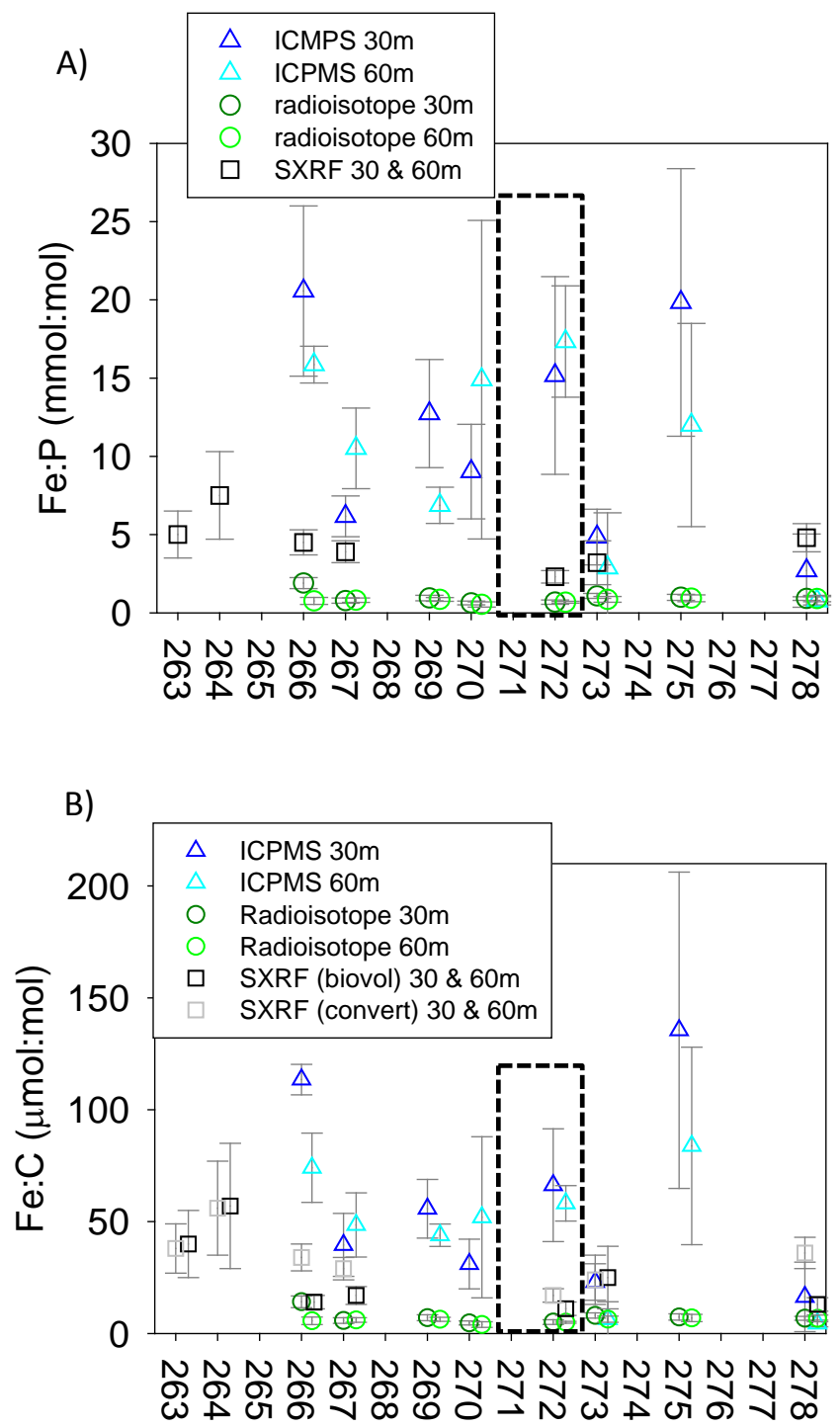

year day

Fig. 5. Comparisons of total particulate $\mathrm{Fe}: \mathrm{P}$ and $\mathrm{Fe}: \mathrm{C}$ ratios using the three different analytical methods at $30 \mathrm{~m}$ and $60 \mathrm{~m}$ over the course of the experiment. (A) Fe:P-based comparison for radioisotope uptake (30 and $60 \mathrm{~m}$; converted using $133 \mathrm{~mol} \mathrm{C:1} \mathrm{mol}$ P), ICPMS-determined BFe and P (30 and $60 \mathrm{~m}$ ), and SXRF (ANCOVA model results) and (B) Fe:C-based comparison for radioisotope uptake (30 and $60 \mathrm{~m}$ ), ICPMS-determined BFe and POC, and SXRF (using both biovolume-based $\mathrm{C}$ estimates and conversion from SXRF-determined $\mathrm{P}$ to $\mathrm{C}$ using $133 \mathrm{~mol} \mathrm{C:1} \mathrm{mol} \mathrm{P).} \mathrm{Error}$ bars for radioisotope- and ICPMS-based quotas represent 1 standard deviation $(n=3)$. Error bars for SXRF-based quotas represent standard error. The transition phase of the study is marked by the dashed line rectangle. For viewing clarity, 30 and $60 \mathrm{~m}$ data, as well as converted and biovolume-based SXRF Fe:C data, are offset by $0.3 \mathrm{~d}$.
Table 5. Least-square means ( \pm standard error; se) of Fe:P and $\mathrm{Fe}: \mathrm{C}$ (C calculated using biovolume estimates) based on taxonomic class described in Table 4 and size class.

\begin{tabular}{lrrrrrr}
\hline & \multicolumn{2}{c}{ Fe:P } & & \multicolumn{2}{c}{ Fe:C } \\
\cline { 2 - 3 } \cline { 6 - 7 } cell type & mean & se & & mean & se \\
\hline Aflag & 3.9 & 0.7 & & 21 & 5 \\
Asterio & 2.7 & 1.1 & & 34 & 17 \\
Apico & 4.7 & 0.9 & & 17 & 4 \\
other & 7.2 & 1.6 & & 16 & 4 \\
\hline $0.2-2 \mu \mathrm{m}$ & 4.4 & 0.9 & & 17 & 4 \\
$2-5 \mu \mathrm{m}$ & 3.5 & 0.6 & & 21 & 5 \\
$5-20 \mu \mathrm{m}$ & 7.5 & 1.7 & & 17 & 5 \\
$>20 \mu \mathrm{m}$ & 2.7 & 1.1 & & 36 & 19 \\
\hline
\end{tabular}

sampling occurred outside the eddy centre (day 278). At these time points, PFe was relatively low (Fig. 4a) and this was perhaps a time when non-living biogenic/detrital particles were a smaller component of the total BFe pool (postbloom conditions). Further investigation is clearly needed to better understand PFe partitioning.

The change in DFe stocks and/or bioavailability over time could have influenced $\mathrm{Fe}$ quotas measured over the study. Fe availability has been shown to influence Fe quotas of a variety of uni-algal cultures (Sunda and Huntsman, 1995). BFe:P quotas were measured from Fe addition and $\mathrm{Fe}$ "removal" by additions of siderophore desferrioxamine B (DFB) in $4 \mathrm{~d}$ long bottle experiments initiated on day 275 of our study. Unamended control bottles resulted in mmol BFe:mol $\mathrm{P}$ of 2.5 , whereas $+\mathrm{Fe}$ and $+\mathrm{DFB}$ treatments resulted in mmol BFe:mol $\mathrm{P}$ of 7.7 and 1.9, respectively (Wilhelm et al., 2012). SXRF measurements of autotrophic flagellated cells collected on the final day of this incubation produced mmol Fe:molP of 3.0 in the presence of added Fe, compared to 2.3 and 1.0 in unamended and DFB-amended treatments. In these incubations, Fe quotas scaled closely with $\mathrm{Fe}$ availability, and a similar relationship may have existed in situ.

At higher Fe concentrations, Fe:C of some cultured phytoplankton can be elevated with no change in growth rate, indicating that cells store excess Fe for later use (Sunda and Huntsman, 1995). Relatively high pre-bloom dissolved $\mathrm{Fe}$ levels in the surface mixed layer $(\sim 0.4-0.6 \mathrm{nM}$ on days 263 , 265, 266, and 276 in Table 1; Boyd et al., 2012; Ellwood et al., 2012) were taken up by the biota, and may have persisted within the particulate pool for some time. For example, results from the open ocean $\mathrm{Fe}$ addition experiment SOIREE indicated that added $\mathrm{Fe}$ remained in surface waters for over $40 \mathrm{~d}$ after addition (Abraham et al., 2000). Furthermore, the $\mathrm{Fe}$-storage protein ferritin can supply $\mathrm{Fe}$ to some bloom-forming pennate diatoms for more than 5 cell 
divisions after DFe supply is curbed (Marchetti et al., 2009), although the dominant diatom species during the present study were not pennates.

Despite the concurrent sample collection during this study, each of the three techniques exhibited a similar trend and range (i.e. 100-fold) to compilations of literature $\mathrm{Fe}: \mathrm{C}$ ratios from a number of other studies conducted in different ocean basins, each with varying nutrient supply regimes (Table 6; Boyd et al., 2007; Twining et al., 2004a, 2011). On four of the five days when all three techniques were employed, bulk BFe:C ratios determined by ICPMS were the largest, followed by SXRF single-cell analysis, then radioisotope uptake ratios (Fig. 5; Table 6). Overall, Fe:C ratios from this study determined by oxalate-washed ICPMS and SXRF were towards the upper bound of $\mathrm{Fe}: \mathrm{C}$ ratios previously reported (Table 6). This may have been an effect of higher initial DFe stocks in prebloom surface waters of our subtropical Pacific study site in comparison to the HNLC Southern Ocean and North Pacific, and also because we sampled a diatomdominated spring bloom during the first portion of the experiment (differing phytoplankton community structure). Below, we discuss the potential assumptions and caveats for each of the three techniques and how they affect the respectively reported $\mathrm{Fe}$ quotas from this study.

\subsection{Radioisotopically-derived Fe:C ratios}

Fe:C ratios determined from radioisotope uptake were among the lowest and varied little between sampling days and size-fractions. Lower $\mathrm{Fe}$ :C uptake ratios on days 270 and 272 were the result of lower chlorophyll-normalized ${ }^{55} \mathrm{Fe}$ uptake. Water column integrated $\mathrm{Fe}$ uptake rates were also relatively lower on days 270 and $272\left(\sim 3 \mu \mathrm{mol} \mathrm{m}^{-2} \mathrm{~d}^{-1}\right.$; Boyd et al., 2012). In the $0.2-2 \mu \mathrm{m}$ size fraction, ${ }^{14} \mathrm{C}$ uptake is presumed to be solely by photosynthetic picoplankton, while ${ }^{55} \mathrm{Fe}$ uptake was likely carried out by both phototrophs and heterotrophic bacteria. Boyd et al. (2012) report that heterotrophic bacteria probably made a significant contribution to Fe uptake in the $0.2-2 \mu \mathrm{m}$ fraction, suggesting that actual $\mathrm{Fe}: \mathrm{C}$ ratios of phytoplankton in this size-fraction would be expected to be lower than the calculated values presented here. For example, Fe:C uptake ratios of heterotrophic bacteria have been reported to be $\sim 2-10$ fold higher than those of eukaryotic phytoplankton (Tortell et al., 1996, 1999; Schmidt and Hutchins, 1999; Strzepek et al., 2005). Based on flow cytometric data collected during the study (Maas, unpublished data) and biovolume conversion estimates used in Strzepek et al. (2005), heterotrophic bacteria accounted for $\sim 80 \%$ of biomass in the $0.2-2 \mu \mathrm{m}$ size fraction. Moreover, cyanobacteria have been found to have higher Fe requirements in comparison to eukaryotic phytoplankton (Brand, 1991; Wilhelm, 1995). In the remaining fractions $(2-5,5-20$, and $>20 \mu \mathrm{m})$, eukaryotic phytoplankton were largely responsible for both Fe and C uptake (Boyd et al., 2012).
In a similar Lagrangian study in a low Fe HNLC subantarctic regime (FeCycle; Boyd et al., 2005), oxalatewashed $\mathrm{Fe}$ and $\mathrm{C}$ uptake in the $0.2-2 \mu \mathrm{m}$ fraction also accounted for the largest fraction of total $\mathrm{Fe}$ and $\mathrm{C}$ uptake ( $\sim 50 \%$ ) (Strzepek et al., 2005; McKay et al., 2005). These two FeCycle studies also reported variability in total $\mathrm{Fe}$ and C uptake with respect to sampling depth (6 depths) within the seasonal mixed layer, but total $\mathrm{Fe}: \mathrm{C}$ uptake ratios did not vary with depth and ranged from 5.5-19 $\mu$ mol Fe:mol C over the sampling period. On the other hand, they reported variability in $\mathrm{FeCycle} \mathrm{Fe}: \mathrm{C}$ uptake ratios amongst size fractions and microbial functional groups - median $\mathrm{Fe}: \mathrm{C}$ in the $0.2-$ $2 \mu \mathrm{m}$ fraction was 17 , while the remaining fractions averaged $\sim 5$ (Strzepek et al., 2005; McKay et al., 2005). Eukaryotic phytoplankton had the lowest $\mathrm{Fe}: \mathrm{C}$ ratios at about 2, while autotrophic flagellates, Synechococcus, and other microzooplankton had $\mathrm{Fe}: \mathrm{C}$ ratios ranging from 8 to 19 (Strzepek et al., 2005; McKay et al., 2005).

Ambient DFe concentrations during our study ranged from $0.03-0.60 \mathrm{nM}$ (Ellwood et al., 2012) and our ${ }^{55} \mathrm{Fe}$ additions were $\sim 0.20 \mathrm{nM}$, equivalent to a 1.3 to 7.6 -fold increase over ambient DFe concentrations. The chlorophyll-normalized Fe uptake rates from water collected at $30 \mathrm{~m}$ on year day 266 were $\sim$ two-fold higher than uptake rates calculated during the rest of the study. We believe that the measured DFe concentration used in the calculation $(0.6 \mathrm{nM})$ may have been higher than in vitro DFe, which would result in higher calculated uptake rates. Alternatively, elevated Fe uptake rates might have been due to higher ambient DFe, since it was well below the half saturation constant for Fe uptake $(4 \mathrm{nM} \mathrm{Fe}$, Maldonado et al., 2001). In experiments with low ambient $\mathrm{DFe}$ (i.e. after year day 268), the addition of radioisotope $\mathrm{Fe}$ could also provide substantial amounts of $\mathrm{Fe}$ for phytoplankton and potentially enhance $\mathrm{Fe}$ uptake during the $24 \mathrm{~h}$ incubation period, resulting in short-term $\mathrm{Fe}: \mathrm{C}$ uptake ratios not fully representative of in situ assemblages. A further complication in the interpretation of Fe uptake data is the concentration and stability constants of in situ Fe-binding ligands, and their kinetics of complexation with the added (unchelated) inorganic ${ }^{55} \mathrm{Fe}$, that could plausibly have an influence on $\mathrm{Fe}$ availability and thus uptake (see Maldonado et al., 2005). In contrast, $\mathrm{C}$ uptake is not likely to be affected by the addition of ${ }^{14} \mathrm{C}$ since the additions were at truly tracer concentrations relative to the ambient dissolved inorganic $\mathrm{C}$ pool. There were also temporal discrepancies (ranging from $30 \mathrm{~min}$ to $12 \mathrm{~h}$ in duration, see Table 1) between the time of collection of samples for DFe measurements and samples for $\mathrm{Fe}$ and $\mathrm{C}$ uptake experiments. This may also have had an effect on calculated Fe uptake rates (see discussion above regarding day 266 - $30 \mathrm{~m}$ sample). 
Table 6. Summary of previously published $\mu$ mol Fe:mol C ratios including values from this study. Based on previously published compilation by Twining et al. (2004b). "Fe:Al corr" refers to the molar Fe:Al ratio used for lithogenic Fe corrections to Fe:C ratios. Fe:C ratios from Martin and Knauer (1973), Martin et al. (1976), and Collier and Edmond (1984) were previously cited by Bruland et al. (1991).

\begin{tabular}{|c|c|c|c|c|c|c|}
\hline Study & Technique & Sample fraction & Location & $\mathrm{Fe}: \mathrm{C}$ & Fe:Al corr & Extracellular wash \\
\hline Martin and Knauer (1973) & GFAAS & $>76 \mu \mathrm{m}$ & Coastal North Pacific & 49 & - & - \\
\hline Martin et al. (1976) & GFAAS & $>64 \mu \mathrm{m}$ & Coastal North Pacific & 47 & - & - \\
\hline Collier and Edmond (1984) & GFAAS & $>44 \mu \mathrm{m}$ & Central South Pacific & 43 & - & - \\
\hline Martin et al. (1989) & GFAAS & $>0.4 \mu \mathrm{m}$ & Central North Pacific & $27-38$ & 0.33 & - \\
\hline Kuss and Kremling (1999) & ICPAES & total & North Atlantic & 26 & - & - \\
\hline Tovar-Sanchez et al. (2003) & GFAAS & $>0.2 \mu \mathrm{m}$ & Southern Ocean & $7-49$ & 0.33 & oxalate-washed \\
\hline Frew et al. (2005) & ICPMS & $>0.2 \mu \mathrm{m}$ & Southern Ocean & $4-12$ & 0.18 & oxalate-washed \\
\hline Ho et al. (2007) & ICPMS & $>150 \mu \mathrm{m}$ & South China Sea & $67-84$ & $0.18-0.33$ & - \\
\hline Twining et al. (2011) & ICPMS & $>3 \mu \mathrm{m}$ & Equatorial Pacific & $20-59$ & - & - \\
\hline this study & ICPMS & $>0.2 \mu \mathrm{m}$ & Subtropical Pacific & $4-136(53 \pm 6)$ & 0.18 & oxalate-washed \\
\hline Twining et al. (2004a) & SXRF & all cell types & Southern Ocean & $6-14$ & - & no wash \\
\hline Twining et al. (2004a) & SXRF & all cell types & Southern Ocean & $10-40$ & - & no wash; in situ $\mathrm{Fe}$ addition \\
\hline Twining et al. (2011) & SXRF & all cell types & Equatorial Pacific & $9-11$ & - & no wash \\
\hline this study & SXRF & all cell types & Subtropical Pacific & $16-34$ & - & no wash \\
\hline Tortell et al. (1996) & Radioisotopes & $>5 \mu \mathrm{m}$ & Central North Pacific & 4 & - & Ti-washed \\
\hline Maldonado and Price (1999) & Radioisotopes & $>3 \mu \mathrm{m}$ & Central North Pacific & 4 & - & Ti-washed \\
\hline Schmidt and Hutchins (1999) & Radioisotopes & $>5 \mu \mathrm{m}$ & Central North Pacific & 9 & - & Ti-washed \\
\hline Abraham et al. (2000) & Radioisotopes & $>0.2 \mu \mathrm{m}$ & Southern Ocean & 3 & - & Ti-washed \\
\hline Twining et al. (2004a) & Radioisotopes & $>3 \mu \mathrm{m}$ & Southern Ocean & 10.4 & - & Ti-washed \\
\hline Mckay et al. (2005) & Radioisotopes & $>0.2 \mu \mathrm{m}$ & Southern Ocean & 10.5 & - & oxalate-washed \\
\hline Sarthou et al. (2007) & Radioisotopes & $>0.2 \mu \mathrm{m}$ & Southern Ocean & $3.0-5.7$ & - & oxalate-washed \\
\hline this study & Radioisotopes & $>0.2 \mu \mathrm{m}$ & Subtropical Pacific & 7 & - & oxalate-washed \\
\hline
\end{tabular}

With the use of tracer additions of $\mathrm{Fe}$ that minimize changes in ambient $\mathrm{DFe}$ and $\mathrm{Fe}$ speciation, calculated Fe uptake rates should reflect in situ uptake rates and thus result in a measurement of steady-state $\mathrm{Fe}: \mathrm{C}$ ratios. In the case of the present study in which ${ }^{55} \mathrm{Fe}$ additions were as high as $\sim 7$-fold, uniform radioisotopic labeling of cells could theoretically occur after $5+$ generations, when $>90 \%$ of cells are labeled (Welschmeyer and Lorenzen, 1984). However, in longer-term uptake experiments (i.e. 6-7 days) with natural assemblages (Tortell et al., 1996; Twining et al., 2004a), the planktonic community has a longer time to respond to the addition of $\mathrm{Fe}$ and/or the effect of being enclosed. These longer experiments measure cellular $\mathrm{Fe}: \mathrm{C}$ ratios rather than the relative rates of uptake, but suffer from the disadvantage of greater potential enclosure artifacts on the community, including changes or succession in community structure.

\subsection{ICPMS-determined BFe:P and BFe:POC}

There was a relatively large range of total $\mathrm{BFe}: \mathrm{P}$ and $\mathrm{BFe}: \mathrm{POC}$ ratios from this study, with the lowest BFe quotas observed in the post-bloom phase of the study on days 273 and 278 (Fig. 3). A primary methodological factor that could have contributed to variability BFe quotas was the determination of $\mathrm{BFe}$ by subtracting a calculated $\mathrm{LFe}$ fraction (using PAl) from the measured PFe (Fig. $4 \mathrm{c}$ and Table 4 of the Supplement). Using this correction methodology, LFe accounted for 80 to $>96 \%$ of the measured PFe pool in the
5-20 and $>20 \mu \mathrm{m}$ size fractions. PAl, and therefore the calculated LFe fraction, was largest in the $>20 \mu \mathrm{m}$ size fraction in non-oxalate washed particulate samples collected at the same time as our study (Ellwood et al., 2012), as well as nonoxalate washed samples during FeCycle (as described above) (Frew et al., 2006). The size spectra of nearby dust particles was found to be in the $2-10 \mu \mathrm{m}$ size range (Hesse and McTainsh, 1999), indicating that some degree of transformation of lithogenic particles in the mixed layer may be occurring (also see Frew et al., 2006).

The use of $\mathrm{Al}$ in suspended particles to estimate the contribution of $\mathrm{Fe}$ from atmospheric dust to the $\mathrm{PFe}$ pool is based on the assumption that $\mathrm{Fe}$ and $\mathrm{Al}$ in a dust particle have not yet been subjected to dissolution processes, or if abiotic and/or biotic dissolution did occur, this and ensuing scavenging behaviors of $\mathrm{Fe}$ and $\mathrm{Al}$ must be equivalent. Unequal dissolution and/or scavenging behaviors would result in a skewed Fe:Al relationship and LFe calculation. Further, we assume an $\mathrm{Fe}: \mathrm{Al}$ ratio of 0.18 for aeolian-delivered lithogenic particles which were derived from both sieved and laboratory-abraded Australian soil samples. These samples are likely representative of dust particles at the FeCycle II study site (Mackie et al., 2008). Previously reported concentrations of crustal $\mathrm{Fe}$ and $\mathrm{Al}$ yield a similar molar $\mathrm{Fe}$ :Al ratio of 0.19-0.34 (Wedepohl, 1995).

Alternative lithogenic correction methods include using $\mathrm{Fe}: \mathrm{Ti}$ and Fe:lithogenic Si from atmospheric dust. While we did not measure lithogenic $\mathrm{Si}$, we did measure particulate 
Ti concentrations from our samples with ICPMS $\left({ }^{47} \mathrm{Ti}\right)$. Fe:Ti molar ratios from the same Australian dust samples described above were $\sim 7$ (Sañudo-Wilhelmy, unpublished data) which agree with previously reported Saharan dust Fe:Ti molar ratios of $\sim 9$ (Borbely-Kiss et al., 2004) and average crustal abundance of $\sim 8-10$ (Wedepohl, 1995). Using this Fe:Ti ratio and our measured particulate Ti concentrations to estimate a $\mathrm{LFe}$ contribution, $\mathrm{BFe}$ for both 30 and $60 \mathrm{~m}$ was $0.27 \pm 0.13 \mathrm{nM}$ (range: $0.04-0.51 \mathrm{nM}$ ), resulting in Ti-corrected BFe:P of $10.6 \pm 6.1$ and BFe:POC of $48 \pm 26$. In comparison, for both 30 and $60 \mathrm{~m}$, mean Fe:Alcorrected $\mathrm{BFe}$ were very similar at $0.30 \pm 0.19 \mathrm{nM}$, as were mean Fe:Al-corrected BFe:P at $10.8 \pm 6.3$ and $\mathrm{BFe}: \mathrm{POC}$ at $50 \pm 32$. The methods used for correcting for lithogenic contributions are strongly dependent on the assumed dust ratios chosen.

Although our study area was far removed from the continental shelf, a sedimentary source of lithogenic Fe is highly likely. The soluble aeolian Fe flux in the vicinity of the study site was relatively small $\left(6.2-55 \mathrm{nmol} \mathrm{m}^{-2} \mathrm{~d}^{-1}\right)$ in comparison to the surface mixed layer DFe inventory of $30 \mu \mathrm{mol} \mathrm{m}{ }^{-2}$ on day 263 , further supporting the assertion that shelf-influenced waters were a significant source of $\mathrm{Fe}$ to this eddy site (Boyd et al., 2012). The sedimentary source of $\mathrm{Fe}$ is also supported by the observation of elevated dissolved Mn at some stations (Ellwood et al., 2012) and by physical modeling, using altimetry of the provenance of the water that eventually formed the eddy sampled during the FeCycle II study (Boyd et al., 2012).

As a qualitative comparison, we calculated molar Fe:Al ratios from National Research Council of Canada marine sediment certified reference materials that were collected from the Beaufort Sea (MESS-3; Fe:Al molar ratio of 0.24), the Hibernia Shelf off Newfoundland (HISS1; $\mathrm{Fe}: \mathrm{Al}=0.16$ ), and Esquimalt Harbor, British Columbia (PACS-2; $\mathrm{Fe}: \mathrm{Al}=0.30$ ). Although the locations of the CRMs are distant from the FeCycle II site, the Fe:Al ratios from Newfoundland sediment are similar to Australian dust and if $\mathrm{LFe}$ was assumed to be primarily shelf-derived, the resulting calculation of $\mathrm{BFe}$ would be similar to our dust-based $\mathrm{LFe}$ correction. However, if the Fe:Al values from the Beaufort Sea or British Columbia were used for a LFe calculation, $\mathrm{BFe}$ would be considerably lower than BFe calculated from our dust $\mathrm{Fe}$ :Al ratio (or zero). Again, using this type of correction is dependent on the assumption that $\mathrm{Fe}$ and $\mathrm{Al}$ in lithogenic particles do not solubilize and/or redistribute at different rates. Nevertheless, identifying and measuring elemental composition of shelf sediments could assist in constraining the supply of Fe from the shelf to the coastal and open ocean.

Apart from lithogenic particles, the ICPMS-determined $\mathrm{BFe}: \mathrm{P}$ and BFe:POC also include phytoplankton and nonphytoplankton particles, such as heterotrophic bacteria in the $0.2-2 \mu \mathrm{m}$ size fraction (as is the case for Fe:C uptake ratios). ICPMS-determined $\mathrm{BFe}$ also likely includes detrital $\mathrm{Fe}-$ the fraction of $\mathrm{Fe}$ in fecal pellets, marine aggregates, or the remains of organisms that may not be oxalate-labile. While this method does not distinguish the contribution of the detrital fraction to $\mathrm{BFe}, \mathrm{P}$, or $\mathrm{POC}$, it can be argued that Fe, $\mathrm{P}$, and $\mathrm{POC}$ values in the detrital pool are as biogeochemicallyrelevant as these are elements in the living biogenic pools and that it is important to include the detrital pool when modeling cycling and biogeochemistry of Fe, P, and POC.

Nevertheless, the differing biological roles of these elements in living and non-living pools underscores the need to develop proxies for detrital $\mathrm{Fe}, \mathrm{P}$, and $\mathrm{C}$, and their contribution to measurements made on suspended particles. Although logistically challenging, a possible candidate proxy could include parameters that integrate biological processes such as chlorophyll:phaeopigment ratios for phytoplankton turnover, or grazer ingestion and egestion rates (fecal pellet production) estimates. For instance, $\mathrm{Fe}: \mathrm{P}$ and $\mathrm{Fe}: \mathrm{C}$ of sinking particles directly below the euphotic zone could be used as a crude estimate of the contribution of detrital $\mathrm{Fe}$ to the calculated BFe. During the study, mean non-oxalate washed BFe:P of sinking particles that were captured in sediment traps over three different deployments ranged from 4.711.4 at $100 \mathrm{~m}$ and $34.1-54.7$ at $200 \mathrm{~m}$ (Twining et al., 2012). The BFe:P ratios increased due to BFe being $~ 1.5-1.7$ times greater at $200 \mathrm{~m}$ compared to $100 \mathrm{~m}$ in combination with a 3.4-4.0 times decrease in P from 100 to $200 \mathrm{~m}$. A similar pattern was observed during FeCycle and FeCycle II (Frew et al., 2006; Twining et al., 2012), in which particulate $C$ and $\mathrm{P}$ were found to be more efficiently remineralized relative to $\mathrm{PFe}$ and thus tended to decrease more rapidly with depth. Increasing BFe:P ratios with depth suggest that remineralization processes and their detrital products will tend to lead to higher particulate $\mathrm{Fe}: \mathrm{P}$, and suggests that the inclusion of detrital $\mathrm{Fe}$ and $\mathrm{P}$ in our water column $\mathrm{BFe}: \mathrm{P}$ ratios might have resulted in an overestimation of phytoplankton BFe:P.

The ICPMS-based approach used in this study is also dependent on the use of an oxalate reagent wash that was used to remove extracellular Fe. The interaction of the oxalate wash with $\mathrm{Fe}$ associated with marine lithogenic particles (of either continental or sedimentary origin) or detritus is presently unknown (Frew et al., 2006). A similar oxalate-based rinse used with soils was found to solubilize a relatively small, but equal, fraction of $\mathrm{Fe}$ and $\mathrm{Al}$ from some amorphous inorganic substances (mean dissolution of $1.5 \%$ of $\mathrm{Fe}$ and $1.3 \%$ for $\mathrm{Al}$ ), while it did not solubilize $\mathrm{Al}$ from crystalline Fe oxides (McKeague, 1967). In $72 \mathrm{~h}$ ${ }^{55} \mathrm{Fe}$ equilibration experiments, about $70 \%$ of ${ }^{55} \mathrm{Fe}$ associated with freshly-precipitated abiotic colloidal and particulate $\mathrm{Fe}$ was found to be removed by washing with oxalate, relative to rinsing with $0.2 \mu \mathrm{m}$ filtered artificial and natural seawater (Hassler and Schoemann, 2009). We did not perform lability digestion assessments (e.g. with weak acids, Chester and Hughes, 1967; Berger et al., 2008), but abiotic/lithogenic particles in our natural samples might have been more refractory. The comparison of ICPMS-based 
$\mathrm{P}$ of oxalate washed samples and colorimetry-based $\mathrm{P}$ of non-oxalate washed samples revealed that the oxalate wash also apparently removed $\sim 40 \%$ of particulate $P$ that was presumably extracellular. The use of non-oxalate washed $\mathrm{P}$ resulted in BFe:P ratios that were $\sim 23-53 \%$ lower than ratios using oxalate washed (intracellular) P. This is consistent with the observation that up to $60 \%$ of cellular P of diatoms and Trichodesmium has been found to be surface adsorbed (Sañudo-Wilhelmy et al., 2004; Fu et al. 2005).

Variability between replicate sample measurements of $\mathrm{BFe}$ quotas was quite large in comparison to the other two approaches (Fig. $4 \mathrm{~d}$ and Table 4 of the Supplement). This is due to relatively variable, and inherently heterogeneous, $\mathrm{PFe}$ pool coupled with large LFe corrections (as discussed above) (Fig. 4c and Table 4 of the Supplement). The relative standard deviation (RSD) of total $\mathrm{BFe}$ measurements ranged from $6-125 \%$ and was on average $41 \%$. In contrast, RSD of $\mathrm{P}$ measurements ranged from $2-19 \%$ and averaged $13 \%$; for POC measurements, RSD ranged from $2-29 \%$ and averaged $7 \%$ (Fig. 1a).

\subsection{SXRF-determined Fe:P and Fe:C}

Single-cell element analysis revealed significant differences in $\mathrm{Fe}$ quotas between taxonomic groups and over the time course of FeCycle II. Asterionellopsis glacialis, the diatom which dominated the bloom, presented the lowest mean Fe:P ratio $(2.7 \mathrm{mmol}: \mathrm{mol})$, while "other diatoms" had significantly higher ratios (7.2 mmol:mol) and non-diatom Fe:P ratios were intermediate (Table 5). The difference in $\mathrm{Fe}$ quotas between the two groups of diatoms is intriguing but was driven largely by differences in cellular $\mathrm{P}$ quotas. $A$. glacialis cells had 5-fold higher P concentrations (152 mM) than the "other diatoms" ( $34 \mathrm{mM})$, while the Fe concentrations in these groups were within $45 \%$ of each other (469 and $323 \mu \mathrm{M}$, respectively). The higher $\mathrm{P}$ content of A. glacialis suggests that these cells contained more rRNA, enabling them to achieve higher growth rates and dominate the bloom (Sterner and Elser, 2002). By comparison, a group of centric diatoms included in the "other diatoms" group were much lower in $\mathrm{P}$. The low $\mathrm{P}$ (and hence high $\mathrm{Fe}: \mathrm{P})$ of this group also drives the size-based group differences. As with the radioisotope-determined Fe quotas, $\mathrm{Fe}: \mathrm{P}$ ratios of the size classes were largely consistent $(2.7-$ $4.4 \mathrm{mmol}: \mathrm{mol})$. However, the 5-20 $\mu \mathrm{m}$ class was significantly higher $(7.5 \pm 1.7 \mathrm{mmol}: \mathrm{mol})$, and this group's mean was driven by the higher Fe:P of the low-P Chaetoceros-like diatoms, all of which fell within this size class (Table 5).

A significant temporal effect in what was also evident in the SXRF dataset, with cellular Fe:P ratios dropping from the beginning of the observational period to the peak of the bloom; Fe:P then rose towards the end (Table 4). Mean Pnormalized $\mathrm{Fe}$ quotas dropped $70 \%$ and $\mathrm{C}$-normalized $\mathrm{Fe}$ quotas dropped $80 \%$ between day 264 (the period of bloom development) and day 272 (following ejection from the eddy center) (Table 5). This was not merely a function of changing community composition: individual autotrophic picoplankton cells from 266 and 272 were analyzed, and Fe:P ratios in this specific functional group dropped $70 \%$ during this time while the inventory of DFe also declined significantly during this time (Boyd et al., 2012). Following the bloom the drifter was ejected from the eddy and DFe and Fe quotas both recovered.

Several aspects of the SXRF methodology entail caveats. While the analyses can be targeted to individual cells and cell types, throughput is limited and sample size is often small. About 130 cells were analyzed from the experiment, representing just merely a fraction of the cell types (and cell diversity) present. However, the dataset includes representatives of the major groups that are $>1 \mu \mathrm{m}$ (picoplankton, monads, diatoms) at the FeCycle II site, and microscopy and flow cytometry counts suggest that the chosen cells are representative (data not shown). Additionally, cellular $\mathrm{C}$ is not measured with the $\mathrm{x}$-ray fluorescence approach utilized here and was instead calculated from cell-specific estimates of biovolume. This introduces some uncertainty in the numbers, as both the biovolume and C:biovolume calculations involve application of generalized relationships that may not apply to each specific cell (Menden-Deuer and Lessard, 2000). However, the average $\mathrm{C}$-based quotas of the mixed phytoplankton community are unlikely to be significantly impacted by volume estimation errors and fixation effects (Menden-Deuer et al., 2001).

\subsection{Recommendations}

The comparison of the three techniques used for determining Fe quotas highlight the differences between biological uptake rates determined over relatively short time scales ( $24 \mathrm{~h}$ ); measurements of an integrated particle reservoir (standing stock) whose history can be influenced by non-living material, and interactions with previous conditions and water masses; and individual cells isolated from a heterogeneous particle assemblage. For instance, DFe inputs on days 263, 265, 266, and 276 (0.4-0.6 nM; DFe from days 265 and 276 from Ellwood et al., 2012) could have been scavenged or actively taken up by phytoplankton and stored and/or recycled for some period of time after the input events, resulting in a decoupling between uptake rate and particulate inventories.

The measurement of particulate $\mathrm{C}$ and $\mathrm{P}$ is also critical to the determination of $\mathrm{Fe}$ quotas. Cellular $\mathrm{P}$ is generally less plastic than cellular $\mathrm{C}$ content (see review by Hutchins et al., 2009) and can be directly measured by ICPMS and SXRF techniques, thus reducing artifacts associated with biovolume or bulk ratio conversions. Cellular P, however, can include intracellular and extracellular fractions (see SañudoWilhelmy et al., 2004). Using P-based quotas may also pose problems in some oceanic regions where $\mathrm{N}$-fixation is dominant and P-limitation might occur. Fe quotas based on cellular $\mathrm{C}$ are biogeochemically-relevant because they directly 
Table 7. Key advantages and disadvantages of Fe quota determination by radioisotope uptake, single-cell SXRF, and bulk ICPMS.

\begin{tabular}{llll}
\hline & Radioisotope uptake & Bulk ICPMS & Single-cell SXRF \\
\hline Advantages & Relatively quick, easy, inexpensive & $\begin{array}{l}\text { Relatively accessible, but moderately } \\
\text { technical and expensive; capable of } \\
\text { multi-elemental analysis }\end{array}$ & $\begin{array}{l}\text { Separates and identifies various } \\
\text { cell types }\end{array}$ \\
& $\begin{array}{l}\text { Measures Fe uptake rate/kinetics, and } \\
\text { Fe:C quota if in steady state }\end{array}$ & Assesses entire particulate reservoir of Fe & $\begin{array}{l}\text { Provides spatial distribution of Fe } \\
\text { (and other trace elements) in } \\
\text { individual cells }\end{array}$ \\
& $\begin{array}{l}\text { Potential bottle effects } \\
\text { Disadvantages }\end{array}$ & $\begin{array}{l}\text { Time-intensive filtration } \\
\text { and sample digestion }\end{array}$ & $\begin{array}{l}\text { Very time intensive, requires } \\
\text { specialized equipment }\end{array}$ \\
& $\begin{array}{l}\text { Increases ambient Fe supply } \\
\text { and/or availability }\end{array}$ & $\begin{array}{l}\text { Requires knowledge about lithogenic } \\
\text { fraction to determine biogenic fraction }\end{array}$ & $\begin{array}{l}\text { Limited sample size, } \\
\text { excludes small cells }(<1 \mu m)\end{array}$ \\
& $\begin{array}{l}\text { Need for carefully-designed Fe tracer } \\
\text { additions to minimize steady-state } \\
\text { perturbations }\end{array}$ & Must use alternate method for C & No direct measurement of C \\
\hline
\end{tabular}

link atmospheric $\mathrm{CO}_{2}$ and the marine biological pump. In terms of practicality, the use of ${ }^{14} \mathrm{C}$ to measure uptake is ubiquitous and methodologically less-challenging in comparison to measuring $\mathrm{P}$ uptake. One must also take into account that $\mathrm{C}, \mathrm{P}$, and $\mathrm{Fe}$ have different remineralization length and time scales that must be taken into consideration when interpreting $\mathrm{Fe}$ quotas of particles subjected to some degree of remineralization (see Twining et al., 2012).

We observed similar discrepancies between the three techniques that were previously noted in Twining et al. (2004a) - low Fe quotas from radioisotope uptake, higher Fe quotas from bulk filtration, and single-cell Fe quotas in between the two other techniques. The three techniques applied to the same water samples also spanned a $\sim 100$-fold range, very similar to previously-measured $\mathrm{Fe}: \mathrm{C}$ quotas compiled from a variety of studies and locations (Boyd et al., 2007). In our study, however, the comparisons made between the three techniques were conducted contemporaneously at the same location using water from the same bottles. Because the discrepancies between the measured Fe quotas were not due to differences in environmental conditions (e.g. resource or nutrient availability) or collection methods, real disparities must exist between uptake rates and pools measured by each technique. Depending on factors such as the contribution of lithogenic and biogenic Fe to the total particulate pool, or phytoplankton community structure, the differences in plankton Fe quotas determined by the three techniques may vary. In uni-algal cultures grown in the same medium, for example, Fe quotas measured by the three techniques yielded similar Fe quotas (Twining et al., 2003, 2004a).

Indeed, the study site could be an important determinant with regards to whether Fe quotas estimated by each technique are expected to agree. In terms of location, our study indicates that bulk filtration-based techniques (i.e. ICPMS, GFAAS) are well suited for characterizing the total PFe pool in regimes that receive continental sources of Fe. In contrast, the radioisotope uptake and single cell techniques reveal little information about the LFe pool. In regions with continental Fe sources, the quantification of BFe pool by bulk filtration techniques requires the use of proxies to separate out LFe. The BFe pool, on the other hand, appears to be better characterized by radioisotopic uptake and single cell techniques which focus on the biological component of the PFe pool.

Another possible factor influencing the comparisons between the three techniques in the present study was the biogeochemical state of flux during the spring bloom and decline. Fe quotas across the course of the spring diatom bloom were not at steady state, with rapid uptake of the initially elevated dissolved Fe being followed by declining uptake rates as ambient supplies were depleted by the bloom. A comparison of the three techniques in a less dynamic and productive regime, such as a stratified summertime gyre system, might have resulted in more comparable Fe quotas.

Each technique has certain advantages or disadvantages and may be more appropriate depending on the nature of the question that needs to be addressed (Table 7). Fe and C uptake experiments, for example, are relatively easy to conduct, but likely perturb the ambient Fe concentration and chemical speciation due to ${ }^{55} \mathrm{Fe}$ addition. However, the use of $\mathrm{pM}$ tracer additions is possible by using ${ }^{55} \mathrm{Fe}$ with high specific activity (see Zubkov et al., 2007) bound to specific organic ligands could minimize this effect (Maldonado et al., 2005). Environmental conditions, including light availability, during deckboard incubations could also have significant effects on uptake. While the relationship between short-term Fe uptake rates and cell quotas is dependent on the assumption 
that the system is in a steady state, this metric is particularly important for constraining the flux of $\mathrm{Fe}$ via biological uptake for Fe cycling budgets (Boyd et al., 2005).

The bulk particle-based ICPMS assessment most likely overestimates biogenic Fe due to the difficulty of separating out the contributions of detrital and lithogenic Fe, despite the use of chemical (oxalate wash) and numerical (subtraction of lithogenic $\mathrm{Fe}$ using $\mathrm{Al}$ or $\mathrm{Ti}$ ) corrections. Lithogenic Fe can be a substantial component of the total particulate Fe pool and in some cases easily overwhelms the small BFe fraction. Both the detrital and lithogenic pools, while not the focus of this particular study, are relevant to the total particulate $\mathrm{Fe}$ pool and Fe cycling in the ocean. While ICPMS can be used to determine $\mathrm{P}$, this method requires a parallel analysis of particulate $\mathrm{C}$ to obtain $\mathrm{Fe}: \mathrm{C}$ quotas.

Fe quotas determined by single-cell SXRF techniques are relatively simpler to interpret. The concentration of Fe (and $\mathrm{P})$ in various cell types are discretely measured. This is critical for constraining plankton-specific pools of $\mathrm{Fe}$ and the differences that may exist between different phytoplankton functional groups or species. The technique is limited by access to instrumentation (thus limiting sample throughput) and cell size $(>\sim 1 \mu \mathrm{m}$, i.e. small cells that have high Fe requirements may be missed), and requires assumptions when normalizing Fe quotas to C. By comparison, equipment used for ICPMS are readily available, enabling substantial throughput advantages, and this technique integrates contributions of the entire community. Both SXRF and ICPMS approaches are capable of providing multi-elemental data.

Because of the differences described above, we contend that the three approaches for characterizing particulate $\mathrm{Fe}$ quotas presented here are highly complementary. Each approach is an inherently different metric (rate versus reservoir of living/non-living particles versus specific living particles), and together generate the most complete understanding of the cycling of $\mathrm{Fe}$ in a particular oceanic locale (e.g. Boyd et al., 2012). They each provide a different yet unique insight into the particulate Fe pool as a whole, as well as into the $\mathrm{Fe}$ content of natural phytoplankton communities, and so a judicious combination of all three may offer the best strategy for realistically incorporating particulate $\mathrm{Fe}$ into quantitative models of global marine biogeochemical cycles (Moore et al., 2004; Krishnamurthy et al., 2009; Galbraith et al., 2010).

\section{Supplementary material related to this article is available online at: http://www.biogeosciences.net/9/667/2012/ bg-9-667-2012-supplement.pdf.}

Acknowledgements. The FeCycle II project was supported by the MSI (New Zealand) funding to the Coasts and Oceans OBI programme (P. W. Boyd, S. Nodder and E. W. Maas) and by grants from the National Science Foundation OCE 0825379/0825405/0825319 to B. S. Twining, S. W. Wilhelm, and D. A. Hutchins, and OCE 0850730 to D. A. Hutchins and F. X. Fu. R. Frew and M. J. Ellwood assisted sampling. H. Chang provided phytoplankton identification and counts. J. Mendez, J. Jacquot, and L. Cutter provided technical assistance at the USC ICPMS facility. We thank E. P. Achterberg and M. T. Maldonado for helpful reviews of our manuscript. Use of the Advanced Photon Source, an Office of Science User Facility operated for the US Department of Energy (DOE) Office of Science by Argonne National Laboratory, was supported by the US DOE under Contract No. DE-AC02-06CH11357. Open access publication costs were awarded to A. L. King by Copernicus Publishing and the $\mathrm{ClimECO}_{2}$ summer school.

Edited by: E. Marañón

\section{References}

Abraham, E. R., Law, C. S., Boyd, P. W., Lavender, S. J., Maldonado, M. T., and Bowie, A. R.: Importance of stirring in the development of an iron-fertilized phytoplankton bloom, Nature, 407, 727-730, 2000.

Berger, C. J. M., Lippiatt, S. M., Lawrence, M. G., and Bruland, K. W.: Application of a chemical leach technique for estimating labile particulate aluminum, iron, and manganese in the Columbia River plume and coastal waters off Oregon and Washington, J. Geophys. Res.-Oceans, 113, C00B01, doi:10.1029/2007JC004703, 2008.

Borbely-Kiss, I., Kiss, A. Z., Koltay, E., Szabo, Gy., and Bozo, L.: Saharan dust episodes in Hungarian aerosol: elemental signatures and transport trajectories, Aerosol Sci., 35, 1205-1224, 2004.

Bowie, A. R., Lannuzel, D., Remenyi, T. A., Wagener, T., Lam, P. J., Boyd, P. W., Guieu, C., Townsend, A. T., and Trull, T. W.: Biogeochemical iron budgets of the Southern Ocean south of Australia: Decoupling of iron and nutrient cycles in the subantarctic zone by the summertime supply, Global Biogeochem. Cy., 23, GB4034, doi:10.1029/2009GB003500, 2009.

Boyd, P. W., Law, C. S., Hutchins, D. A., Abraham, E. R., Croot, P. L., Ellwood, M., Frew, R. D., Hadfield, M., Hall, J., Handy, S., Hare, C., Higgins, J., Hill, P., Hunter, K. A., Leblanc, K., Maldonado, M. T., Mckay, R. M., Mioni, C., Oliver, M., Pickmere, S., Pinkerton, M., Safi, K., Sander, S., SañudoWilhelmy, S. A., Smith, M., Strzepek, R., Tovar-Sanchez, A., and Wilhelm, S. W.: FeCycle: Attempting an iron biogeochemical budget from a mesoscale SF6 tracer experiment in unperturbed low iron waters, Global Biogeochem. Cy., 19, GB4S20, doi:10.1029/2005GB002494, 2005.

Boyd, P. W., Jickells, T., Law, C. S., Blain, S., Boyle, E. A., Buesseler, K. O., Coale, K. H., Cullen, J. J., de Baar, H. J. W., Follows, M., Harvey, M., Lancelot, C., Levasseur, M., Owens, N. P. J., Pollard, R., Rivkin, R. B., Sarmiento, J., Schoemann, V., Smetacek, V., Takeda, S., Tsuda, A., Turner, S., and Watson, A. J.: Mesoscale iron enrichment experiments 1993-2005: Synthesis and future directions, Science, 315, 612-617, 2007.

Boyd, P. W., Strzepek, R., Chiswell, S., De Bruyn, J., Ellwood, M., Keenan, S., King, A. L., Maas, E., Nodder, S., Sander, S., Sutton, P., Twining, B. S., Wilhelm, S., and Hutchins, D. A.: Decoupling of iron and carbon biogeochemistry during a spring diatom bloom, 2012.

Brand, L. E.: Minimum iron requirements of marine phytoplankton and the implications of biogeochemical control of new produc- 
tion, Limnol. Oceanogr., 36, 1756-1771, 1991.

Bruland, K. W., Donat, J. R., and Hutchins, D. A.: Interactive influences of bioactive trace metals on biological production in oceanic waters, Limnol. Oceanogr., 36, 1555-1577, 1991.

Chester, R. and Hughes, M. J.: A chemical leach technique for the separation of ferromanganese minerals, carbonate minerals, and absorbed trace elements from pelagic sediment, Chem. Geol., 2, 249-262, 1967.

Coale, K. H., Johnson, K. S., Fitzwater, S. E., Gordon, R. M., Tanner, S., Chavez, F. P., Ferioli, L., Sakamoto, C., Rogers, P., Millero, F., Steinberg, P., Nightingale, P., Cooper, D., Cochlan, W. P., Landry, M. R., Constantinou, J., Rollwagen, G., Trasvina, A., and Kudela, R.: A massive phytoplankton bloom induced by an ecosystem-scale iron fertilization experiment in the equatorial Pacific Ocean, Nature, 383, 495-501, 1996.

Collier, R. and Edmond, J.: The trace-element geochemistry of marine biogenic particulate matter, Progr. Oceanogr., 13, 113-199, 1984.

Cullen, J. J.: Hypotheses to explain high-nutrient conditions in the open sea, Limnol. Oceanogr., 36, 1578-1599, 1991.

Cullen, J. T. and Sherrell, R. M.: Techniques for determination of trace metals in small samples of size-fractionated particulate matter: phytoplankton metals off central California, Mar. Chem., 67, 233-247, 1999.

de Baar, H. J. W., Boyd, P. W., Coale, K. H., Landry, M. R., Tsuda, A., Assmy, P., Bakker, D. C. E., Bozec, Y., Barber, R. T., Brzezinski, M. A., Buesseler, K. O., Boye, M., Croot, P. L., Gervais, F., Gorbunov, M. Y., Harrison, P. J., Hiscock, W. T., Laan, P., Lancelot, C., Law, C. S., Levasseur, M., Marchetti, A., Millero, F. J., Nishioka, J., Nojiri, Y., van Oijen, T., Riebesell, U., Rijkenberg, M. J. A., Saito, H., Takeda, S., Timmermans, K. R., Veldhui, S M. J. W., Waite, A. M., and Wong, C. S.: Synthesis of iron fertilization experiments: From the iron age in the age of enlightenment, J. Geophys. Res.-Oceans, 110, 1-24, 2005.

Eggimann, D. W. and Betzer, P. R.: Decomposition and analysis of refractory oceanic suspended materials, Anal. Chem., 48, 886890,1976

Ellwood, M. J.: Wintertime trace metal ( $\mathrm{Zn}, \mathrm{Cu}, \mathrm{Ni}, \mathrm{Cd}, \mathrm{Pb}$ and Co) and nutrient distributions in the Subantarctic Zone between 40-52 ${ }^{\circ}$; 155-160 E, Mar. Chem., 112, 107-117, 2008.

Ellwood, M. J., Nodder, S. D., Boyd, P. W.: Trace metal cycling during a subtropical spring bloom event in the Southwestern Pacific Ocean, in preparation, 2012.

Frew, R. D., Hutchins, D. A., Nodder, S., Sañudo-Wilhelmy, S., Tovar-Sanchez, A., Leblanc, K., Hare, C. E., and Boyd, P. W.: Particulate iron dynamics during FeCycle in subantarctic waters southeast of New Zealand, Global Biogeochem. Cy., 20, GB1S93, doi:10.1029/2005GB002558, 2006.

Fu, F.-X., Zhang, Y., Leblanc, K., Sañudo-Wilhelmy, S. A., and Hutchins, D. A.: The biological and biogeochemical consequences of phosphate scavenging onto phytoplankton cell surfaces, Limnol. Oceanogr., 50, 1459-1472, 2005.

Fung, I. Y., Meyn, S. K., Tegen, I., Doney, S. C., John, J. G., and Bishop, J. K. B.: Iron supply and demand in the upper ocean, Global Biogeochem. Cy., 14, 281-295, 2000.

Galbraith, E. D., Gnanadesikan, A., Dunne, J. P., and Hiscock, M. R.: Regional impacts of iron-light colimitation in a global biogeochemical model, Biogeosciences, 7, 1043-1064, doi:10.5194/bg-7-1043-2010, 2010.
Hassler, C. S. and Schoemann, V.: Discriminating between intraand extracellular metals using chemical extractions: an update on the case of iron, Limnol. Oceanogr.-Meth., 7, 479-489, 2009.

Heese, P. P. and McTainsh, G. H.: Last Glacial Maximum to early Holocene wind strength in the mid-latitudes of the Southern Hemisphere from Aeolian dust in the Tasman Sea, Quat. Res. 52, 343-349, 1999.

Hillebrand, H., Durselen, C. D., Kirschtel, D., Pollingher, U., and Zohary, T.: Biovolume calculation for pelagic and benthic microalgae, J. Phycol., 35, 403-424, 1999.

Ho, T. Y., Quigg, A., Finkel, Z. V., Milligan, A. J., Wyman, K., Falkowski, P. G., and Morel, F. M. M.: The elemental composition of some marine phytoplankton, J. Phycol., 39, 1145-1159, 2003.

Ho, T. Y., Wen, L. S., You, C. F., Lee, D. C.: The trace-metal composition of size-fractionated plankton in the South China Sea: Biotic versus abiotic sources, Limnol. Oceanogr., 52, 1776-1788, 2007.

Hutchins, D. A. and Bruland, K. W.: Iron-limited diatom growth and $\mathrm{Si}$ : $\mathrm{N}$ uptake ratios in a coastal upwelling regime, Nature, 393, 561-564, 1998.

Hutchins, D. A., Mulholland, M. R., and Fu, F.: Nutrient cycles and marine microbes in a $\mathrm{CO}_{2}$-enriched ocean, Oceanography, 22, 128-145, 2009.

Krishnamurthy, A., Moore, J. K., Mahowald, N., Luo, C., Doney, S. C., Lindsay, K., and Zender, C. S.: Impacts of increasing anthropogenic soluble iron and nitrogen deposition on ocean biogeochemistry, Global Biogeochem. Cy., 23, GB3016, doi:10.1029/2008GB003440, 2009.

Kuss, J. and Kremling, K.: Spatial variability of particle associated trace elements in near-surface waters of the North Atlantic $\left(30^{\circ} \mathrm{N} / 60^{\circ} \mathrm{W}\right.$ to $\left.60^{\circ} \mathrm{N} / 2^{\circ} \mathrm{W}\right)$, derived by large-volume sampling, Mar. Chem., 68, 71-86, 1999.

Leblanc, K., Hare, C. E., Boyd, P. W., Bruland, K. W., Sohst, B., Pickmere, S., Lohan, M. C., Buck, K., Ellwood, M., and Hutchins, D. A.: Fe and $\mathrm{Zn}$ effects on the Si cycle and diatom community structure in two contrasting high and low-silicate HNLC areas, Deep-Sea Res. I, 52, 1842-1864, 2005.

Mackie, D. S., Boyd, P. W., McTainsh, G. H., Tindale, N. W., Westberry, T. K., and Hunter, K. A.: Biogeochemistry of iron in Australian dust: From eolian uplift to marine uptake, Geochem. Geophys. Geosy., 9, Q03Q08, doi:10.1029/2007GC001813, 2008.

Maldonado, M. T. and Price, N. M.: Utilization of iron bound to strong organic ligands by plankton communities in the subarctic Pacific Ocean, Deep-Sea Res. II, 46, 2447-2473, 1999.

Maldonado, M. T. and Price, N. M.: Reduction and transport of organically bound iron by Thalassiosira oceanica (Bacillariophyceae), J. Phycol., 37, 298-309, 2001.

Maldonado, M. T., Boyd, P. W., Strzepek, R., LaRoche, J. L., Waite, A., Croot, P. L., and Price, N. M.: Phytoplankton physiological responses to changing iron chemistry during a mesoscale Southern Ocean iron-enrichment, Limnol. Oceanogr., 46, 1802-1808, 2001.

Maldonado, M. T., Strzepek, R. F., Sander, S., and Boyd, P. W.: Acquisition of iron bound to strong organic complexes, with different Fe binding groups and photochemical reactivities, by plankton communities in Fe-limited subantarctic waters, Global Biogeochem. Cy., 19, GB4S23, doi:10.1029/2005GB002481, 2005. Maldonado, M. T., Zubkov, M. V., Holland, R. J., Burkill, P. H., 
Croudace, I. W., and Warwick, P. E.: Microbial abundance, activity and iron uptake in the vicinity of the Crozet Isles in November 2004-January 2005, Deep Sea Res. II, 54, 2126-2137, 2007.

Marchetti, A., Parker, M. S., Moccia, L. P., Lin, E. O., Arrieta, A. L., Ribalet, F., Murphy, M. E. P., Maldonado, M. T., and Armbrust, E. V.: Ferritin is used for iron storage in bloom-forming marine pennate diatoms, Nature, 457, 467-470, 2009.

Martin, J. H. and Knauer, G. A.: The elemental composition of plankton, Geochim. Cosmochim. Acta, 37, 1639-1653, 1973.

Martin, J. H. and Fitzwater, S. E.: Iron-deficiency limits phytoplankton growth in the northeast Pacific Subarctic, Nature, 331, 341-343, 1988

Martin, J. H., Bruland, K. W., and Broenkow, W. W.: Cadmium transport in the California Current, in: Marine Pollutant Transfer, edited by: Windom, H. and Duce, R., Heath, 159-184, 1976.

Martin, J. H., Gordon, R. M., Fitzwater, S., and Broenkow, W. W.: Vertex - Phytoplankton iron studies in the Gulf of Alaska, DeepSea Res. I, 36, 649-680, 1989.

McKay, R. M. L., Wilhelm, S. W., Hall, J., Hutchins, D. A., Al Rshaidat, M. M. D., Mioni, C. E., Pickmere, S., Porta, D., and Boyd, P. W.: Impact of phytoplankton on the biogeochemical cycling of iron in subantarctic waters southeast of New Zealand during FeCycle, Global Biogeochem. Cy., 19, GB4S23, doi:10.1029/2005GB002481, 2005.

McKeague, J. A.: An evaluation of $0.1 \mathrm{M}$ pyrophosphate and pyrophosphate-dithionite in comparison with oxalate as extractants of the accumulation products in podzols and some other soils, Can. J. Soil Sci., 47, 95-99, 1967.

Menden-Deuer, S. and Lessard, E. J.: Carbon to volume relationships for dinoflagellates, diatoms, and other protist plankton, Limnol. Oceanogr., 45, 569-579, 2000.

Menden-Deuer, S., Lessard, E. J., and Satterberg, J.: Effect of preservation on dinoflagellate and diatom cell volume and consequences for carbon biomass predictions, Mar. Ecol. Prog. Ser., 222, 41-50, 2001.

Moore, J. K., Doney, S. C., Glover, D. M., and Fung, I. Y.: Iron cycling and nutrient-limitation patterns in surface waters of the World Ocean, Deep-Sea Res. II, 49, 463-507, 2002.

Moore, J. K., Doney, S. C., and Lindsay, K.: Upper ocean ecosystem dynamics and iron cycling in a global threedimensional model, Global Biogeochem. Cy., 18, GB4028, doi:10.1029/2004GB002220, 2004.

Murphy, R. J., Pinkerton, M. H., Richardson, K. M., BradfordGrieve, J., and Boyd, P. W.: Phytoplankton distributions around New Zealand derived from SeaWIFS remotely-sensed ocean colour data, New Zeal. J. Mar. Fresh., 35, 343-362, 2001.

Nodder, S. D., Sutton, P., Kennan, S., Boyd, P. W., Ellwood, M. J., Schwarz, J., Maas, E. W., Chang, F. H. Wilhelm, S. W., DeBruyn, J., Strzpek, R. F., King, A. L., Hutchins, D. A., Law, C. S., and Northcote, L.: Spring bloom evolution in a warm-core subtropical eddy, Southwestern Pacific Ocean, in preparation, 2012.

Nunez-Milland, D. R., Baines, S. B., Vogt, S., and Twining, B. S.: Quantification of phosphorus in single cells using synchrotron X-ray fluorescence, J. Synchrotron Radiat., 17, 560-566, 2010.

Parekh, P., Follows, M. J., and Boyle, E. A.: Decoupling of iron and phosphate in the global ocean, Global Biogeochem. Cy., 19, GB2020, doi:10.1029/2004GB002280, 2005.

Parsons, T. R., Maita, Y., and Lalli, C. M.: A manual of chemical and biological methods for seawater analysis, Pergamon Press,
Oxford, New York, 63-100, 1984.

Quigg, A., Finkel, Z. V., Irwin, A. J., Rosenthal, Y., Ho, T. Y., Reinfelder, J. R., Schofield, O., Morel, F. M. M., and Falkowski, P. G.: The evolutionary inheritance of elemental stoichiometry in marine phytoplankton, Nature, 425, 291-294, 2003.

Sañudo-Wilhelmy, S. A., Tovar-Sanchez, A., Fu, F. X., Capone, D. G., Carpenter, E. J., and Hutchins, D. A.: The impact of surfaceadsorbed phosphorus on phytoplankton Redfield stoichiometry, Nature, 432, 897-901, 2004.

Sarthou, G., Vincent, D., Christaki, U., Obernosterer, I., Timmermans, K. R., and Brussaard, C. P. D.: The fate of biogenic iron during a phytoplankton bloom induced by natural fertilisation: Impact of copepod grazing, Deep-Sea Res. II, 55, 734-751, 2008.

Schmidt, M. A. and Hutchins, D. A.: Size-fractionated biological iron and carbon uptake along a coastal to offshore transect in the Northeastern Pacific, Deep-Sea Res. II, 46, 2487-2503, 1999.

Sigman, D. M. and Boyle, E. A.: Glacial/interglacial variations in atmospheric carbon dioxide, Nature, 407, 859-869, 2000.

Solorzano, L. and Sharp, J. H.: Determination of total dissolved phosphorus and particulate phosphorus in natural-waters, Limnol. Oceanogr., 25, 754-757, 1980.

Sterner, R. W and Elser, J. J.: Ecological Stoichiometry, Princeton University Press, Princeton, 439 pp., 2002.

Strzepek, R. F., Maldonado, M. T., Higgins, J. L., Hall, J., Safi, K., Wilhelm, S. W., and Boyd, P. W.: Spinning the "Ferrous Wheel": The importance of the microbial community in an iron budget during the FeCycle experiment, Global Biogeochem. Cy., 19, GB4S26, doi:10.1029/2005GB002490, 2005.

Sunda, W. G. and Huntsman, S. A.: Iron uptake and growth limitation in oceanic and coastal phytoplankton, Mar. Chem., 50, 189-206, 1995.

Sunda, W. G. and Huntsman, S. A.: Interrelated influence of iron, light and cell size on marine phytoplankton growth, Nature, 390, 389-392, 1997.

Sunda, W. G. and Huntsman, S. A.: Relationships among photoperiod, carbon fixation, growth, chlorophyll- $a$, and cellular iron and zinc in a coastal diatom, Limnol. Oceanogr., 49, 1742-1753, 2004.

Tang, D. G. and Morel, F. M. M.: Distinguishing between cellular and Fe-oxide-associated trace elements in phytoplankton, Mar. Chem., 98, 18-30, 2006.

Tortell, P. D., Maldonado, M. T., and Price, N. M.: The role of heterotrophic bacteria in iron-limited ocean ecosystems, Nature, 383, 330-332, 1996.

Tortell, P. D., Maldonado, M. T., Granger, J., and Price, N. M.: Marine bacteria and biogeochemical cycling of iron in the oceans, Fems Microbiol. Ecol., 29, 1-11, 1999.

Tovar-Sanchez, A. and Sañudo-Wilhelmy, S. A.: Influence of the Amazon River on dissolved and intra-cellular metal concentrations in Trichodesmium colonies along the western boundary of the sub-tropical North Atlantic Ocean, Biogeosciences, 8, 217 225, doi:10.5194/bg-8-217-2011, 2011.

Tovar-Sanchez, A., Sañudo-Wilhelmy, S. A., Garcia-Vargas, M., Weaver, R .S., Popels, L. C., and Hutchins, D. A.: A trace metal clean reagent to remove surface-bound iron from marine phytoplankton, Mar. Chem., 82, 91-99, 2003.

Twining, B. S., Baines, S. B., Fisher, N. S., Maser, J., Vogt, S., Jacobsen, C., Tovar-Sanchez, A., and Sañudo-Wilhelmy, S. A.: 
Quantifying trace elements in individual aquatic protist cells with a synchrotron X-ray fluorescence microprobe, Anal. Chem., 75, 3806-3816, 2003.

Twining, B. S., Baines, S. B., Fisher, N. S., and Landry, M. R.: Cellular iron contents of plankton during the Southern Ocean Iron Experiment (SOFeX), Deep-Sea Res. I, 51, 1827-1850, 2004a.

Twining, B. S., Baines, S. B., and Fisher, N. S.: Element stoichiometries of individual plankton cells collected during the Southern Ocean Iron Experiment (SOFeX), Limnol. Oceanogr., 49, 2115-2128, 2004b.

Twining, B. S., Baines, S. B., Bozard, J. B., Vogt, S., Walker, E. A., and Nelson, D. M.: Metal quotas of plankton in the equatorial Pacific Ocean, Deep-Sea Res. II, 58, 325-341, 2011.

Twining, B. S., Nodder, S. D., King, A. L., Hutchins, D. A., LeCleir, G. R., DeBruyn, J. M., Maas, E. W., Vogt, S., Wilhelm, S. W, and Boyd, P. W.: Maps of major and trace elements in sinking diatoms reveal differential remineralization, in preparation, 2012.

Vogt, S.: A set of software tools for analysis and visualization of 3D x-ray fluorescence data sets, J. Phys. IV, 104, 635-638, 2003.

Vogt, S., Maser, J., and Jacobsen, C.: Data analysis for X-ray fluorescence imaging, J. Phys. IV, 104, 617-622, 2003.
Wedepohl, K. H.: The composition of the continental-crust, Geochim. Cosmochim. Acta, 59, 1217-1232, 1995.

Welschmeyer, N. A.: Fluorometric analysis of chlorophyll a in the presence of chlorophyll- $b$ and phaeopigments, Limnol. Oceanogr. 39, 1985-1992, 1994.

Welschmeyer, N. A. and Lorenzen, C. J.: Carbon-14 labeling of phytoplankton carbon and chlorophyll- $a$ carbon: Determination of specific growth rates, Limnol. Oceanogr., 29, 135-145, 1984.

Wilhelm, S. W.: Ecology of iron-limited cyanobacteria: a review of physiological responses and implications for aquatic systems, Aquat. Microb. Ecol., 9, 295-303, 1995.

Wilhelm, S. W., King, A. L., Twining, B. S., LeCleir, G. R., DeBruyn, J. M., Matteson, A. R., Strzepek, R. F., Breene, C., Boyd, P. W., and Hutchins, D.A.: The effects of iron availability on cellular nutrient quotas for algae and communities in the Southern Pacific Ocean, in preparation, 2012.

Zar, J. H.: Biostatistical Analysis, 3rd Ed., Prentice-Hall, Upper Saddle River, NJ, USA, 1996. 